\title{
Cyclodextrins in Drug Delivery Systems and Their Effects on Biological Barriers
}

\author{
Ádám Haimhoffer ${ }^{1,2, \dagger}{ }^{\text {, Ágnes Rusznyák }}{ }^{1,2,+}$, Katalin Réti-Nagy ${ }^{1}$, Gábor Vasvári ${ }^{1,2}$, \\ Judit Váradi ${ }^{1}$, Miklós Vecsernyés ${ }^{1}$, Ildikó Bácskay ${ }^{1}$, Pálma Fehér ${ }^{1}$, Zoltán Ujhelyi ${ }^{1}$ \\ and Ferenc Fenyvesi ${ }^{1, *}$ \\ 1 Department of Pharmaceutical Technology, Faculty of Pharmacy, University of Debrecen, Nagyerdei St. 98, \\ H-4032 Debrecen, Hungary; haimhoffer.adam@pharm.unideb.hu (Á.H.); \\ rusznyak.agnes@pharm.unideb.hu (Á.R.); retinagykatalin@pharm.unideb.hu (K.R.-N.); \\ vasvari.gabor@pharm.unideb.hu (G.V.); varadi.judit@pharm.unideb.hu (J.V.); \\ vecsernyes.miklos@pharm.unideb.hu (M.V.); bacskay.ildiko@pharm.unideb.hu (I.B.); \\ feher.palma@pharm.unideb.hu (P.F.); ujhelyi.zoltan@pharm.unideb.hu (Z.U.) \\ 2 Doctoral School of Pharmaceutical Sciences, University of Debrecen, H-4032 Debrecen, Hungary \\ * Correspondence: fenyvesi.ferenc@pharm.unideb.hu \\ + These authors contributed equally to this work.
}

Received: 24 September 2019; Accepted: 13 November 2019; Published: 20 November 2019

check for updates

\begin{abstract}
Cyclodextrins are widely used excipients, composed of glucopyranose units with a cyclic structure. One of their most important properties, is that their inner cavity is hydrophobic, while their surface is hydrophilic. This enables them for the complex formation with lipophilic molecules. They have several applications in the pharmaceutical field like solubility enhancers or the building blocks of larger drug delivery systems. On the other hand, they have numerous effects on cells or biological barriers. In this review the most important properties of cyclodextrins and cyclodextrin-based drug delivery systems are summarized with special focus on their biological activity.
\end{abstract}

Keywords: cyclodextrins; drug delivery systems; biological barriers; nanopharmaceutics

\section{Introduction}

Cylodextrins are cyclic, non-reducing oligosaccharides composed of glucopyranose units [1]. The $\alpha-, \beta$-, and $\gamma$-cyclodextrins are widely known, which contain 6,7 , and 8 units respectively. Recently the smallest cyclodextrins were synthetized, containing 3 and 4 glucopyranose units [2], and on the other hand big oligosaccharides with more, than 8 units are also known [1] and applied for complexation [3] or as chiral selectors for enantiomeric pharmaceuticals [4]. Glucopyranose units form a conical cylinder, which has a hydrophobic inner cavity and a hydrophilic outer surface. This structure enables them to form inclusion complexes with hydrophobic molecules. In general, the complex forming abilities of $\alpha-, \beta$-, and $\gamma$-cyclodextrins are better, than the larger ones, thus these derivatives are practically important [1]. Cyclodextrin rings can be chemically modified, linked with substituents or other cyclodextrin rings and used to build up larger nanostructures. The type and application of these nano-constructs is continuously increasing. Besides the drug complexation, cyclodextrins can form complexes with natural, biological important molecules like phospholipids, cholesterol or other lipophilic molecules. It causes various effects, especially at cellular level or on biological barriers. On the other hand, cholesterol complexation properties of hydroxypropyl- $\beta$-cyclodextrin is applied in the treatment of Niemann Pick Disease Type C (NPC) and was approved as an orphan drug. This mini-review gives a summary on the basic complexation, drug delivery and biological properties of cyclodextrins and the cyclodextrin-based nano-scale drug delivery systems. 


\section{Cyclodextrin Complex Formation}

Cyclodextrins are widely used excipients in pharmaceutical formulations and the interest in cyclodextrin research and application is still significant. The most common application of cyclodextrins is the solubility and bioavailability enhancement of poorly water-soluble drugs by complexation. These drugs belong to the Class 2 (low solubility, high permeability) or Class 4 (low solubility, low permeability) of the Biopharmaceutics Classification System (BCS) and by the application of cyclodextrins both their solubility and permeability can be improved [5] (Figure 1). Nevertheless, the possibilities for the improvement of the properties of Class 4 drugs by cyclodextrins is limited.
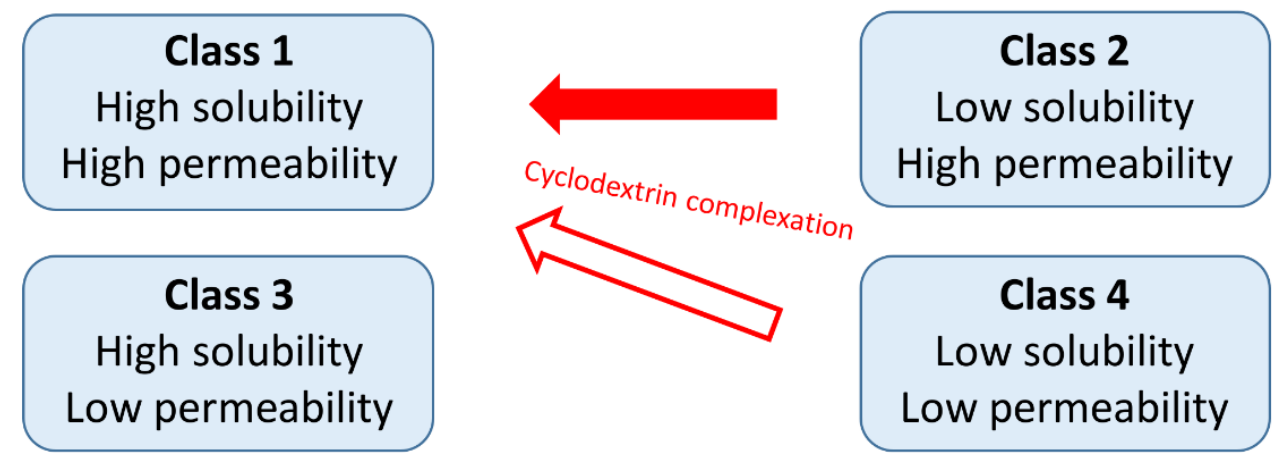

Figure 1. The relationship between the Biopharmaceutics Classification System and the effects of cyclodextrin complexation.

Increasing the cyclodextrin concentration in a solution the concentration of dissolved drug is usually increasing, but exceptions can be found. These relationships can be described by the phase-solubility diagrams (Figure 2), [6]. A-type phase-solubility curves show the increased drug solubility by increasing cyclodextrin concentration. $\mathrm{A}_{\mathrm{L}}$-type diagrams indicate that the solubility of the guest molecule increases linearly with cyclodextrin concentrations. AP-type diagrams show positive deviation from linearity, suggesting the presence of higher-order complexes for cylodextrins. $A_{N}$-type diagrams have negative deviation from linearity and may be explained by the self-association or aggregation of the cyclodextrins or their complexes, decreasing the solubility of the drug. In the case of B-type curves the formed complexes have limited solubility in the aqueous medium. $\mathrm{B}_{\mathrm{S}}$-type profiles show the development of complexes with reduced aqueous solubility with the maximal solubility at the plateau. In the case of $\mathrm{B}_{\mathrm{i}}$-type profiles the formed complexes are insoluble in the applied solvent. The affinity of a drug for a certain cyclodextrin can be characterized by the stability constant (K) of the drug-cyclodextrin complex. In these descriptions the drug:cyclodextrin ratio is usually considered to be $1: 1$ or 1:2, but higher ratios can also exist. Nevertheless, higher-order complex aggregates may be formed and affect the solubility of the drug [7]. Self-association of lipophilic drugs molecules and drug-cyclodextrin complexes contributes to the non-inclusion complexation, which influences the shape and the interpretation of the curves. As a result, the stoichiometry of drug-cyclodextrin complexes cannot be determined in each cases from the phase-solubility diagrams [8].

Even if the complex formation with cyclodextrins is mainly used for the solubility enhancement of poorly water-soluble drugs, this phenomenon takes place with natural lipophilic molecules if their size and molecular structure are suitable for the host-guest interaction. Interaction with natural molecules (e.g., cholesterol and lipid membrane components or vitamins) can be characterized by the phase-solubility diagrams and have also significant importance in biomedical research and application. 


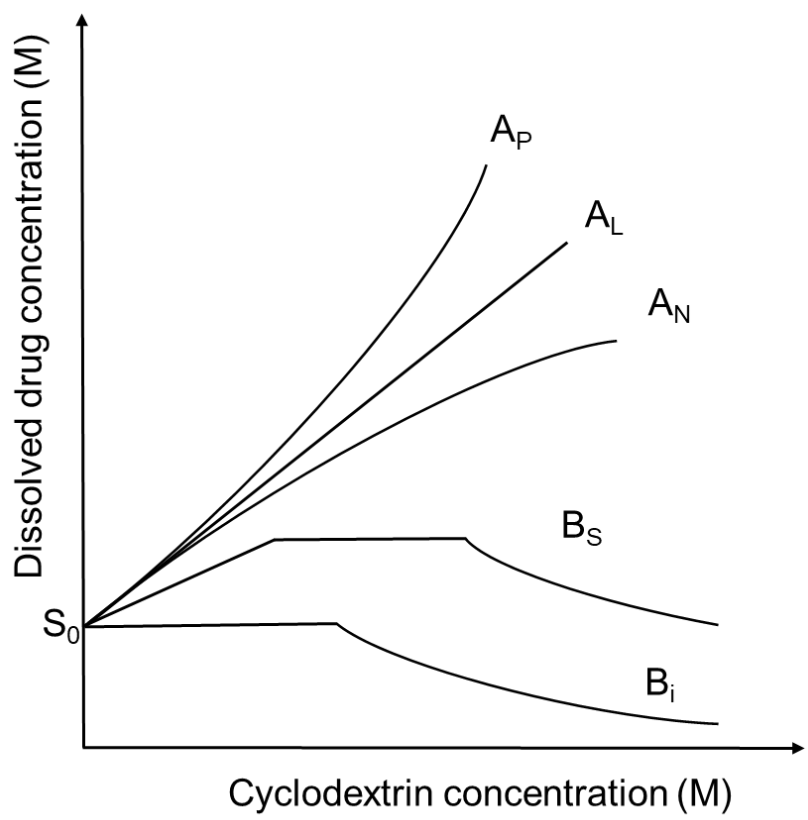

Figure 2. Phase solubility diagrams and their classification according to Higuchi and Connors. $\mathrm{S}_{0}$ is the intrinsic solubility of drugs in aqueous medium.

\section{Cyclodextrin-Based Nanostructures}

\subsection{Cyclodextrin Associates, Polypseudorotaxanes and Polyrotaxanes}

Besides the association of lipophilic drug molecules and drug-cyclodextrin complexes, the aggregation of cyclodextrin molecules is also a known phenomenon [9]. $\alpha-, \beta-$, and $\gamma$-cyclodextrins form aggregates in concentrated $(\mathrm{mM})$ solutions and bind together by a network of hydrogen bonds and by intermediate, bridging water molecules. These wormlike, self-assembled aggregates of cyclodextrins might be called "poly-CD". The optimal configuration for the neighboring cyclodextrin rings is the "head-to-head/tail-to-tail" orientation [10]. Mixing of the concentrated aqueous solution of $\alpha$-cyclodextrin with the polymer polyethylene-glycol (PEG) [11] or $\beta$-cyclodextrin with poly(propylene glycol) [12] causes the cooperative threading of the cyclodextrin molecules along a single polymeric chain. These mixtures become turbid and a precipitate is formed, but the process is reversible. The assembly is called polypseudorotaxane [10]. Pegylated molecules maintain their ability to form polypseudorotaxane. Pegylated insulin forms polypseudorotaxanes with alpha- and gamma-CDs, by inserting one or two PEG chains in the CD's cavity respectively [13] and coumarin linked PEG chains form polypseudorotaxanes with alpha-CDs arranging in supramolecular micelles [14]. If the two ends of the polymer chain are linked to two bulky end groups and the cyclodextrin rings are prevented from dethreading, the structure is called polyrotaxane [15]. It is a mechanically interlocked molecule, like a molecular necklace, where no covalent bonds can be found between the cyclodextrin rings, but the cyclodextrins remain on their axles. Several types of cyclodextrins and water soluble and insoluble polymers were used for the formation of polyrotaxanes and different strategies were established for their synthesis, which was extensively reviewed earlier [16]. Polyrotaxanes are widely used in the formation of drug delivery systems. Both the $\mathrm{CD}$ ring and the polymer chain can be functionalized for the improved efficiency or cellular internalization. Recently $\alpha$-CD ring was modified with $\alpha$-D-mannose for the improved mannose receptor mediated endocytosis [17]. Folate-terminated polyrotaxanes were developed by modifying PEG chains and target mitochondrium [18]. Polyrotaxane-based theranostics were also fabricated with excellent anti-tumor performance [19]. Cationic cyclodextrin polyrotaxanes can be also used for the cellular delivery of polynucleotides [20] and genes [21].

Besides the association and mechanical interlocking, chemical modification or polymerization of cyclodextrin rings is the other possibility to build up cyclodextrin-based nanostructures. Cyclodextrins 
are also used for the formation of the variety of other nano-scale drug delivery systems like cyclodextrin polymers and nanosponges.

\subsection{Formation of Cyclodextrin Conjugates, Polymers, and Nanosponges}

In addition to intermolecular forces, it is also possible to modify the cyclodextrins by functional groups and build up larger structures by covalent bonds. The 2,3,6-hydroxyl groups of the cyclodextrin ring are reactive and can be modified by the ways mentioned below. The hydroxyl groups show different reactivity, the $2,6-\mathrm{OH}$ is the most reactive [22]. The modification of the hydroxyl groups can help the extensive usability of cyclodextrins in the pharmaceutical development. The basic methods for the synthesis of modified cyclodextrins are deprotonation, dehydration and condensation. In the case of deprotonation, the reaction of acidic hydroxyl group with a strong base produces an anion which needs to the SN2-type polymerizations. The most common cross-linker, epichlorohydrin, also reacts with the CD-ring by this mode. The dehydration method creates polyethers and polyesters. A typical reaction of cyclodextrins happens with diol or diacid in sulphuric acid solution. The third type is the condensation which means the reaction of cyclodextrins directly with a bi-functional linker such as diisocyanate [23]. Depending on the linker, the reaction results many kinds of molecular structures, the most typical ones are schematically shown on Figure 3. These are discussed in more detail in later paragraphs.

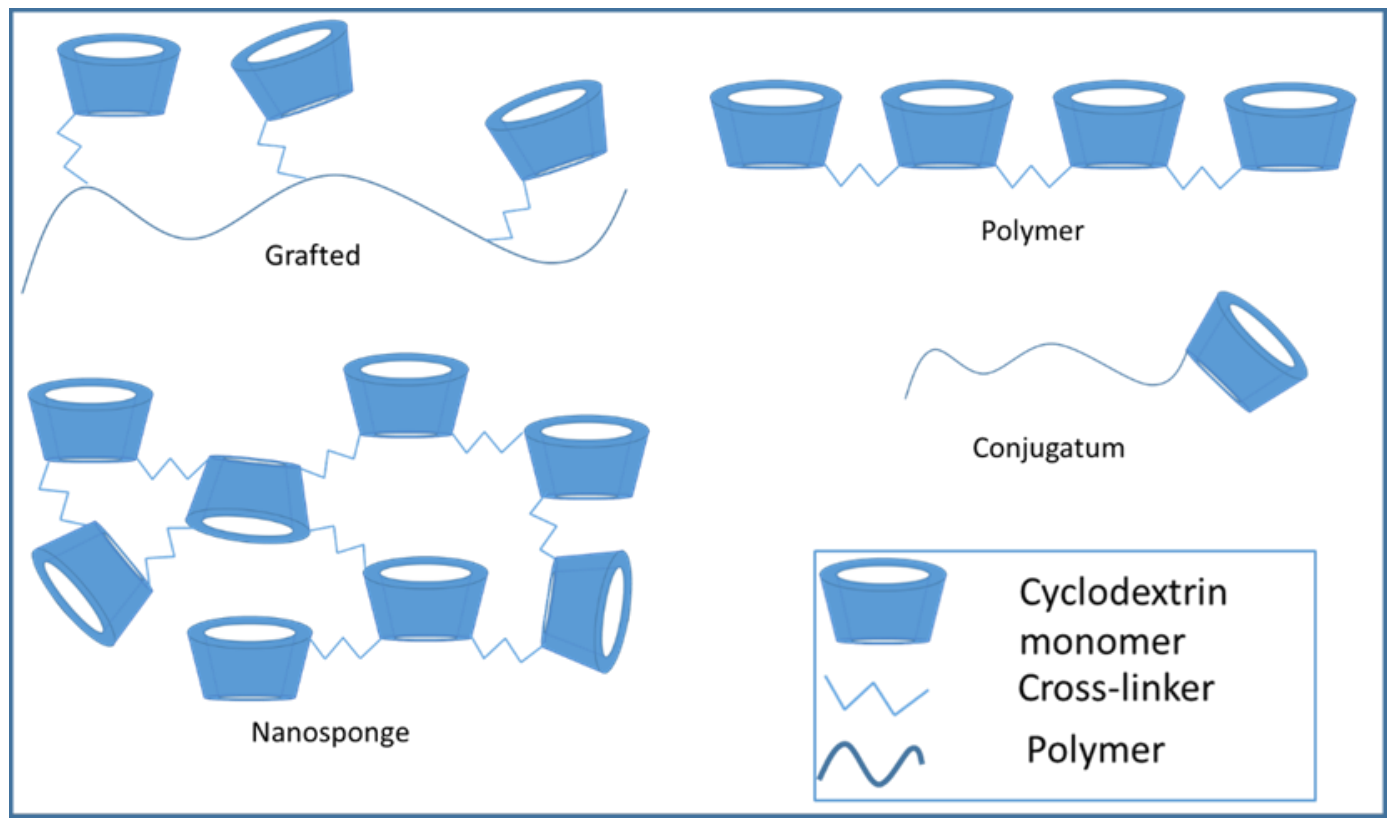

Figure 3. Cyclodextrin conjugates, polymers, and nanosponges.

\subsection{Mucoadhesive Drug Carriers}

Grafted cyclodextrins can ensure improved mucoadhesion of the complex to the absorption areas. This modification is useful in sublingual, gastroretentive, or vaginal applications. The best known materials that have mucoadhesive properties are polyethylene-glycol, chitosan, alginate, or molecules having thiol groups [24].

Thiolated cyclodextrins are the smallest mucoadhesive drug carriers, it can be formulated from $\alpha$-cyclodextrin, $\beta$-cyclodextrin, or $\gamma$-cyclodextrin [25]. Cysteamine conjugated $\beta$-cyclodextrin can be a new promising excipient for oral drug delivery. It shows a significant buccal mucoadhesion, and increases the solubility of a model drug, miconazole nitrate [26]. Another study used thiolated $\alpha$-cyclodextrin to reach prolonged ocular drug release. The encapsulated cetirizine reduced the irritation of the rabbit ocular mucosa. Comparison of the complex solution with cetirizine solution showed, that after $24 \mathrm{~h}$ the effects of cetirizine solution disappeared, but the complex was effective 
up to $72 \mathrm{~h}$ [27]. Thiolated cyclodextrin complexes can be used for the protection of vaginal mucosa from viral infection [28]. The studies showed that the carrier is not cytotoxic on different cell cultures. Prolonged residence time was further increased and the thiol group was protected by disulphide bond formation using 2-mercaptonicotinic acid [29].

Cyclodextrins were also grafted to chitosan and alginate to increase the ability of mucoadhesion. These structures are larger, than the thiolated cyclodextrins. Chitosan grafted with cyclodextrins has less mucoadhesivity than chitosan alone, but still higher than cyclodextrins and these modifications are suitable for prolonged drug release [30]. After the grafting and entrapping the drug, the complex showed self-aggregation $[31,32]$. Eugenol was also formulated with $\beta$-cyclodextrin-grafted chitosan derivatives. Eugenol complexed with $\beta$-cyclodextrin-grafted chitosan showed higher antimicrobial activity against Candida albicans, Streptococcus oralis, and Streptococcus mutans, than the native $\beta$-cyclodextrin-grafted chitosan [31]. Jun Wang et al. developed nanospheres with doxorubicin-hydrochloride and cyclodextrin grafted chitosan. The nanoparticles showed a continuous drug release until $200 \mathrm{~h}$, in the first $24 \mathrm{~h} 18 \%$ of the drug released, and after, the release rate slowed down and reached $40 \%$ finally. These results point out that drugs with good solubility can be formulated with chitosan to sustained drug delivery in cancer therapeutics [33].

Alginate grafted cyclodextrins can be formulated to hydrogel, nano-, or microbeads. Hydrogels which are prepared by $\mathrm{CaCl}_{2}$ is softer than the pure alginate, however it has mucoadhesive properties and encapsulates insoluble drugs [34]. $\mathrm{CaCl}_{2}$ solution is used to formulate beads, $\mathrm{Ca}^{2+}$ ion makes ionic bonds between two alginate polymer chains [35].

\subsection{Responsive Cyclodextrins}

Sensitive, smart drug delivery systems were developed, which change their properties responding to thermo-, pH-, or photo-stimuli. The responsive functionalities are based on host-guest interactions, additional responsive moieties, supramolecular interactions or a polymer [36]. As it was described above, the first thermo-responsive cyclodextrin-based system was the $\alpha$-cyclodextrin-PEG polypseudorotaxane, which precipitates during its formation in aqueous solution, but the complexes can be dissolved in water by heating [11]. The thermo-responsive cyclodextrin, which is conjugated with a polymer, has a critical working temperature. Most of the cases, its solubility is altered by temperature changing which is called lower or upper critical solution temperature [37]. On the other hand, the temperature also influences the swelling ratio of the formed gel that is closely related to the rate of dissolution and erosion. The most common polymers, which are used for the preparation of thermo-responsive systems are $N$-isopropylacrylamide, acrylamide, acryl acid and poly(ethylene glycol) [38-40].

The $\mathrm{pH}$ sensitive drug delivery systems can be useful to treat tumor diseases. The tumor microenvironment has lower $\mathrm{pH}$, than the blood or other tissues. The smart system is able to recognize the changing of the $\mathrm{pH}$ and releases the active ingredient [41,42]. On the other hand, the $\mathrm{pH}$ of the stomach is also less than the colon $\mathrm{pH}$, so using $\mathrm{pH}$ sensitive polymer can help to avoid the harmful effects of low $\mathrm{pH}[36,38]$. The mechanism for cyclodextrins is that, the chargeable cyclodextrin molecule entraps the active pharmaceutical ingredients (API) and the $\mathrm{pH}$ changes alters the surface charge. That transformation is able to leak the drug from the cyclodextrin cavity [43].

The photo-responsive carriers contain photoreactive compounds for example azobenzene-poly-2(diisopropylamino) ethyl methacrylate-methoxypolyethylene glycols. This copolymer was inserted into the host $\beta$-cyclodextrins. The azo group has a cis-trans reversibly isomerism, that are transformed into one another by near-infrared light (NIR, $980 \mathrm{~nm}$ ) and caused the reversible insertion into the cyclodextrin ring [44].

Table 1. summarizes the latest investigations in this topic. 
Table 1. Latest results on stimuli-responsive cyclodextrin drug delivery systems.

\begin{tabular}{|c|c|c|c|c|c|c|}
\hline Stimulus & Conjugates/Guests & Cyclodextrin & Drug & Effect & Application & Ref. \\
\hline Temperature & poly(ethylene glycol) (PEG) & $\alpha-C D$ & $\begin{array}{l}\text { No active ingredient } \\
\text { was used }\end{array}$ & Convert from gel to sol state. & $\begin{array}{l}\text { Biomedical using as local chemotherapy } \\
\text { of cancers, excellent cytocompatibility, } \\
\text { controlled drug release. }\end{array}$ & [12] \\
\hline Temperature & bi-perylene monoimide & permethyl- $\beta-C D$ & $\begin{array}{l}\text { Tetraphenylporphine } \\
\text { (TPPS) }\end{array}$ & LCST shows from $32{ }^{\circ} \mathrm{C}$ to $48.2^{\circ} \mathrm{C}$. & $\begin{array}{l}\text { Controlled drug release that is } \\
\text { depending on the temperature }\end{array}$ & [45] \\
\hline Temperature and $\mathrm{pH}$ & $\mathrm{N}$-isopropylacrylamide & $\beta-C D$ & Naproxen sodium & $\begin{array}{l}\text { Swollen ratio decreased with the } \\
\text { increase of temperature and } \\
\text { response to } \mathrm{pH} \text { is depending on \% } \\
\text { of the component }\end{array}$ & $\begin{array}{c}\text { Hydrogels show biodegradability and } \\
\text { controlled drug release in stomach } \\
\text { condition; in intestinal condition the } \\
\text { release is faster because of the higher } \\
\mathrm{pH} .\end{array}$ & [38] \\
\hline Temperature and $\mathrm{pH}$ & chitosan & $\beta-C D$ & Etoposide (VP16) & $\begin{array}{l}\text { thermo-sensitive hydrogen bonds } \\
\text { were between API and the } \beta \text {-CD } \\
\text { cavity that is damaged by } \\
\text { increasing temperature. Release of } \\
\text { the drug reached } 90 \% \text { at } \mathrm{pH} 4.5\end{array}$ & $\begin{array}{l}\text { The } \mathrm{pH} \text { response is important to treat } \\
\text { cancer, because the tumors' } \\
\text { microenvironment is acidic, contrast } \\
\text { with the blood } \mathrm{pH} \text {. }\end{array}$ & [46] \\
\hline Temperature and $\mathrm{pH}$ & $\mathrm{N}$-isopropylacrylamide & $\beta-C D$ & Doxorubicin (DOX) & $\begin{array}{l}\text { The release of DOX was enhanced } \\
\text { by the increase of temperature and } \\
\text { decrease of } \mathrm{pH}\end{array}$ & $\begin{array}{l}\text { It is a supramolecular micelle for } \\
\text { anticancer therapy. Therapeutic index is } \\
\text { higher than free DOX. }\end{array}$ & [39] \\
\hline $\mathrm{pH}$ & $\begin{array}{l}\text { L-phenylalanine functionalized graphene } \\
\text { oxide }\end{array}$ & $\beta-C D$ & Doxorubicin (DOX) & $\begin{array}{l}\text { Changing the } \mathrm{pH} \text { from } 7.2 \text { to } 5.4 \\
\text { resulted in triplicated drug release } \\
\text { of DOX. }\end{array}$ & $\begin{array}{l}\text { Nanocarrier has excellent } \\
\text { biocompatibility, and is a pH-responsive } \\
\text { drug delivery system for cancer therapy }\end{array}$ & [47] \\
\hline $\mathrm{pH}$ & $\begin{array}{l}\text { zinc oxide nanoparticles with functionalized } \\
\text { PEG surface }\end{array}$ & $\beta-C D$ & Curcumin & $\begin{array}{c}\mathrm{pH} \text { stimulated release showed zero } \\
\text { order release of curcumin at tumor } \\
\mathrm{pH}\end{array}$ & $\begin{array}{l}\text { ZnO nanoparticles have higher } \\
\text { antibacterial activity on Staphylococcus } \\
\text { Aureus than free drug }\end{array}$ & [48] \\
\hline $\mathrm{pH}$ & chitosan & $\beta-C D$ & $\begin{array}{l}\text { Methyl-orange (not } \\
\text { active pharmaceutical } \\
\text { ingredients (API)) }\end{array}$ & $\begin{array}{l}\text { Swelling behaviours were changed } \\
\text { by pH stimuli }\end{array}$ & $\begin{array}{c}\text { It has sustained release properties, } \\
\text { which make it suitable for use in } \\
\text { medicine }\end{array}$ & [49] \\
\hline $\mathrm{pH}$ and photo & $\begin{array}{l}\text { azobenzene-poly-2-(diisopropylamino) ethyl } \\
\text { methacrylate-methoxypolyethylene glycols }\end{array}$ & $\beta-C D$ & doxorubicin (DOX) & $\begin{array}{l}\text { The low pH and NIR lead to } \\
\text { disassembling of nanoparticles. }\end{array}$ & $\begin{array}{c}\text { It provides a new perspective on tumor } \\
\text { therapy, tumor targeting, and controlled } \\
\text { drug release. }\end{array}$ & [44] \\
\hline $\mathrm{pH}$ & adamantyl-terminated poly (ethylene glycol) & $\begin{array}{l}\beta \text {-cyclodextrin-containing } \\
\text { poly( } \beta \text {-amino ester })\end{array}$ & Curcumin & $\begin{array}{c}\text { Micelle could unload the } 70 \% \text { of } \\
\text { drug at pH } 5.5 \text { and } 30 \% \text { of the drug } \\
\text { at } 7.4 \text { until } 24 \text { hours. }\end{array}$ & $\begin{array}{l}\text { It is a supramolecular micelle drug } \\
\text { delivery system for cancer treatment. }\end{array}$ & [50] \\
\hline reduction, photo & hyaluronic acid & $\beta-\mathrm{CD}$ & $\begin{array}{l}\text { adamantane linked } \\
\text { camptothecin }\end{array}$ & $\begin{array}{l}\text { Disulphide bond linkage is } \\
\text { reduction sensitive, that is led to } \\
\text { release the drug by NIR }\end{array}$ & $\begin{array}{l}\text { A reduction-sensitive drug delivery was } \\
\text { developed with } \\
\text { photothermal-chemotherapy. }\end{array}$ & [51] \\
\hline
\end{tabular}




\subsection{Cyclodextrin Polymers}

Cyclodextrin polymers offer significant opportunities to the application of cyclodextrins. The structure increases the chance for interactions between the cyclodextrin cavity and guest drugs [52]. Depending on the reaction, and the substituents it is possible to create soluble or insoluble polymers. The solubility decreases as the number of connected monomers increases, and this parameter depends on the reactivity of the cross-linker agent, substituents, and the reaction time $[23,53,54]$. The most common cross-linkers are epichlorhydrin and citric acid [52,55-57]. The water-insoluble cyclodextrins today are used as a solid phase to remove pollution from solutions and used in analytical chemistry [58-61]. The oral usability of solid, water insoluble, cyclodextrin polymer as a microsize-controlled drug delivery system is a promising tool for the formulation of controlled drug delivery systems. Intensive investigations are needed to develop this field of cyclodextrin applications and utilize its possibilities.

Nanosponge (NS) is a type of insoluble cyclodextrin polymer that has highly cross-linked 3D network structure. Its size is around 200-300 nm [62]. NS offers possibility to increase the solubility of insoluble drugs, the permeability of the drugs and controlled drug release (Figure 4).
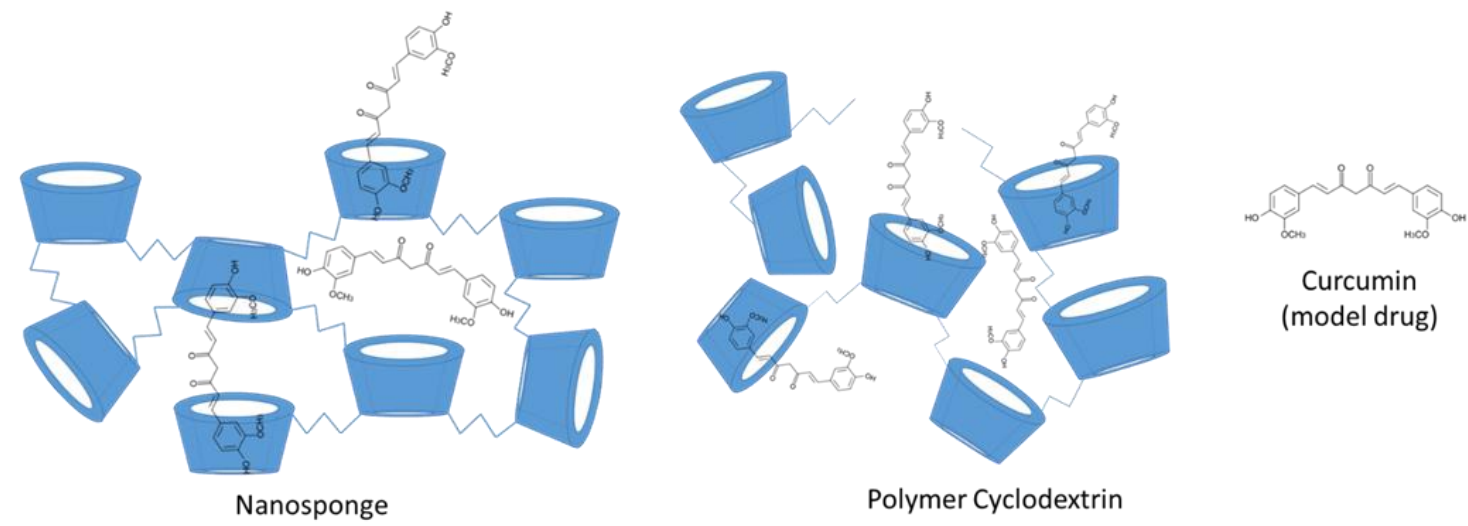

Figure 4. The structure of cyclodextrin nanosponge and polymer cyclodextrin with the model guest molecule curcumin.

Taking into account their properties, cyclodextrin NS can be generally classified into four generations [63] (Figure 5). First generation NSs are prepared by the cross linking of cyclodextrin rings by suitable cross-linker. After synthesis drugs are loaded into NSs during a complexation step. Second NSs are functionalized and have specific properties such as fluorescence or electric charge. Functionalization can be done before synthesis of NS (pre-cross-linking functionalization of cyclodextrins), during the cross-linking step adding the functionalizing agent or after synthesis (post-cross-linking functionalization of NS). Finally, the complexation of drugs is performed. Third generation NSs are stimuli-sensitive systems and have responsive properties to external changes such as the chemical environment. Fourth generation NSs are prepared by molecular imprinting method. 


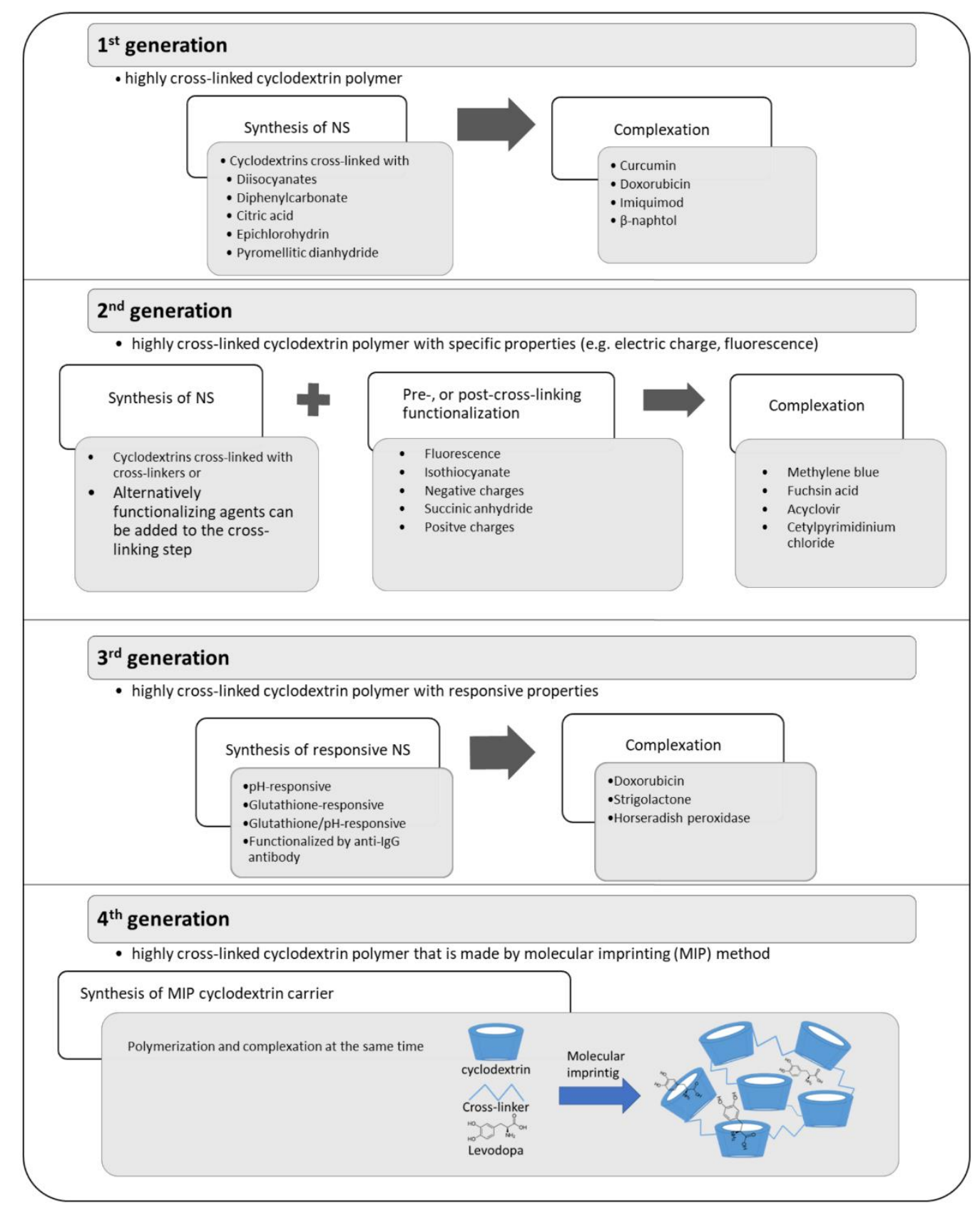

Figure 5. Generation of nanosponges (NS). (References: 1st generation [64-70], 2nd generation [71-75], 3rd generation [76-79], and 4th generation [80,81]).

\subsection{Amphiphilic Cyclodextrins}

A special group of cyclodextrin derivatives are the amphiphilic cyclodextrins. In these derivatives hydrophobic (aliphatic) chains are grafted on the primary and/or secondary face of the cyclopdetxrin rings. These cyclodextrins can self-assemble into water soluble aggregates, like micelles and nanoparticles or insert in lipid membranes [82]. With these amphiphilic cyclodextrins cell targeting can be improved. There are two groups of these cyclodextrins. One of is the polysubstituted amphiphilic cyclodextrins which were obtained by the substitution of the primary or secondary hydroxyl groups. According to the position of the substitution groups we can distinguish some sub-groups, such as medusa-like, skirt-shaped, and bouquet-like (Figure 6). The medusa-like cyclodextrins were synthetized by the persubstitution of the primary side with sulfo-, thio-, alkyl-, amido-, or amino chains. This type can form a stable Langmuir-Blodgett layer. The skirt- shaped type were modified on the secondary 
hydroxyl groups with alkyl chains via an ester group. Bouquet-like amphiphilic cyclodextrins contain hydrocarbon chains on both sides, thus increasing their hydrophobicity. These derivatives can also contain a poly(oxyethylene) or a polymethylene chain on each side of the cavity. Another family of polysubstituted cyclodextrins contains hydrophobic alkyl chains on one side and hydrophilic chains on the other side [83]. These derivatives can form bilayer vesicles, thus the hydrophilic chains at the surface increase their colloidal stability and potentially decreasing their adverse immune response. The other group of the amphiphilic cyclodextrins is the monosubstituted amphiphilic cyclodextrins. These excipients obtained by appending a single hydrophobic anchor. The aim of this derivatization is the improvement of cell targeting. This group also has some sub-groups. The "Lollipop" is obtained by grafting an alkyl chain on the primary side. The "Cup and Ball" derivative contain a bulky Boc-amino protective group at the end of the alkyl chain. This cyclodextrin is much more water-soluble than the "Lollipop" cyclodextrin. In the case of the lipid-like amphiphilic cyclodextrins the hydrophobicity was increased with a lipid-like anchor such as cholesteryl or phospholipidyl group (Table 2) [82,83].

Table 2. Types of amphiphilic cyclodextrins with substituents.

\begin{tabular}{|c|c|c|}
\hline $\begin{array}{l}\text { Type of Amphiphilic } \\
\text { Cylodextrin }\end{array}$ & Subtype & Substituents \\
\hline \multirow{3}{*}{ Polysubstituted } & Medusa-like & Sulfo-, thio-alkyl-, amido- or, amino chains on the primary side \\
\hline & Skirt shaped & $\begin{array}{c}\text { Modified on the secondary hydroxyl groups with alkyl chains } \\
\text { via an ester group }\end{array}$ \\
\hline & Bouquet-like & $\begin{array}{l}\text { Hydrocarbon chains on boths side, or poly(oxyethylene) and } \\
\text { polymethylene chains }\end{array}$ \\
\hline \multirow{3}{*}{ Monosubstituted } & Lollipop & One alkyl chain on the primary side \\
\hline & Cup and Ball & $\begin{array}{l}\text { Contain a bulky Boc-amino protective group at the end of the } \\
\text { alkyl chain }\end{array}$ \\
\hline & Lipid-like & Cholesteryl, phospholipidyl or dilauryl moiety \\
\hline
\end{tabular}

Based on the charging of the amphiphilic cyclodextrins we can distinguish two types. The cationic cyclodextrins can be obtained by the modification of the oligomer (oligo(ethylene glycol) side chains with amino groups [84]. The anionic cyclodextrins contain carboxyl or sulphate groups [85]. Amphiphilic cyclodextrins can form self-assembled nanoparticles. This property can improve the cell targeting, the tumoral penetration, the drug release profiles and cytotoxicity. Ghera et al. made stable aqueous suspension of nanoparticles by using nanoprecipitation without a surface-active agent. Amphiphilic cyclodextrins were dissolved in a polar solvent, like acetone or ethanol and the solution was poured into water and stirred at $400 \mathrm{rpm}$. The solvent was evaporated under reduced pressure. They stored the suspensions of nanospheres at $+4{ }^{\circ} \mathrm{C}$ and found that the suspensions were stable over at least 9 month [86]. Amphiphilic cyclodextrins were used for the formation of drug delivery systems of wide range of drug molecules or biomolecules. Amphiphilic $\alpha$-cyclodextrins were used to form self-assembled supramolecular nanoparticles and improved the cytotoxicity of a CK2 inhibitor [87]. Amphiphilic cyclodextrins were also studied as non-viral vectors for gene or nucleic-acid delivery, especially polycationic derivatives are suitable to interact with the anionic nature of nucleic acids [82]. Nevertheless modified PEGylated amphiphilic cyclodextrins [88] were used for siRNA delivery and galactosylated amphiphilic cyclodextrins were tested for targeted gene delivery to hepatocytes [89]. PEGylated cyclodextrin-based nanoparticle, tagged with central nervous system (CNS)-targeting peptide derived from the rabies virus glycoprotein was tested as potential carrier of siRNA, targeting brain cancer [78]. Active targeting can be also achieved by folate-decorated amphiphilic cyclodextrins, which enhanced the cellular uptake of nanoassemblies into tumor cells overexpressing $\alpha$-folate receptors [90]. 

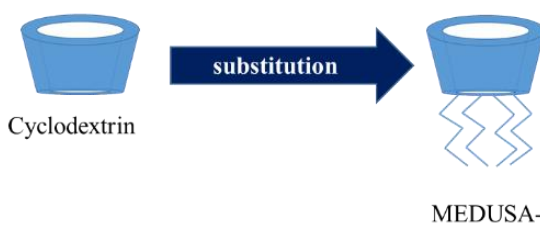
like

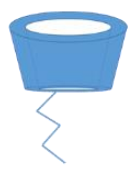

Lollipop
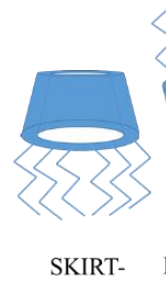
shaped

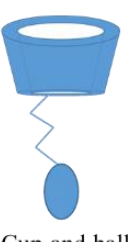

Cup-and-ball

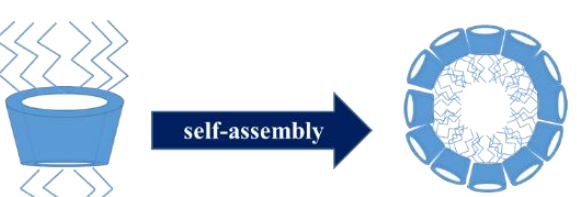

Supramolecular structures (nanoparticles, micelles)

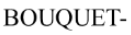
shaped$$
\text { shaped }
$$

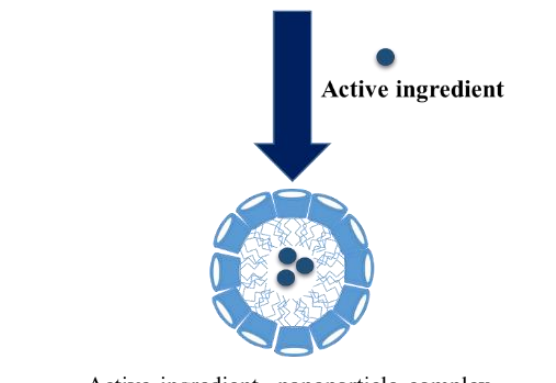

Active ingredient- nanoparticle complex

Figure 6. Amphiphilic cyclodextrins: structure, self-association and drug loading.

To understand the drug delivery properties of cyclodextrin-based nanoparticles, the diverse interactions of cyclodextrins and cyclodextrin nanoparticles with cell membranes and biological barriers should be discussed.

\section{Cyclodextrins, Biological Barriers and the Significance of Lipid and Cholesterol Complexation}

Because of their well-known properties, cyclodextrins have several indirect and direct effects on biological barriers. The intestinal barrier and blood-brain barrier are widely investigated, but cell membrane should be also mentioned as the elemental component of the biological barriers. As we discussed above these molecules can form complexes with lipophilic drugs, hereby improving their water solubility and carrying them to the barrier surface. Firstly, guest molecule can be transported through the unstirred water layer (UWL) of the intestinal barrier as a complex (with proper stability constant). UWL can be $100 \mu \mathrm{m}$ thick, and it is absorbed to the surface of viscous mucus membranes [91-93]. There is a limitation in case of hydrophilic cyclodextrins: transportation is only possible when resistance of UWL on donor side is equal or higher than the resistance of membrane barrier $[93,94]$. Ren et al. confirmed with in silico simulations that $\beta$-cyclodextrins (and assemblies with $\beta$-cyclodextrins) confronting with large energy barriers to penetrate biological membranes [95]. So $\beta$-cyclodextrins can improve water solubility of lipophilic drugs by complexation and enhance bioavailability of the guest molecule by transporting it directly to the barrier membrane, where the complex dissociates, and the free drug can be absorbed [96]. This process supposes not too strong binding force between the cyclodextrin and the complexed drug (otherwise complex dissociation cannot take place) [92] and the presence of not more cyclodextrin molecules than necessary for solubilization, because excess amount of cyclodextrin decreases bioavailability of the complexed drug [93].

Based on the host-guest interaction, cyclodextrins can form complexes with natural hydrophobic molecules. $\alpha$-cyclodextrins form complexes with phospholipids, while for $\beta$-cyclodextrins membrane cholesterol is an excellent cellular target. Cholesterol is a key component of the cell membrane, representing ca. 30\% of total lipids [97]. Due to their affinity for these biomolecules, $\alpha$-cyclodextrins extract phospholipids from the membrane $[98,99]$ and $\beta$-cyclodextrins induce the release of cellular cholesterol [100], thus cyclodextrins have direct effects on cells and biological barriers. Monnaert et al. found that extent of lipid solubilization from brain endothelial cells depends on the cyclodextrin ring size: $\beta>>\gamma>\alpha$-cyclodextrin for cholesterol, $\alpha>>\gamma>\beta$-cyclodextrin for phosphatidylcholine and $\alpha>\beta>>\gamma$-cyclodextrin for sphingomyelin [101]. Cyclodextrin-cell membrane interactions have several dose-dependent effects, but structure-activity relationships were also revealed, which depend on both the type of cyclodextrins and the substituents of the cyclodextrin ring. Both $\alpha$ - and $\beta$-cyclodextrins can cause dose-dependent hemolysis $[98,99,102]$ and cytotoxicity [103], but the substituents have 
great impact on these effects. We showed, that there is a correlation between the cytotoxic effect, hemolytic activity and the cholesterol complexation properties of $\beta-C D$ derivatives [103]. Cytotoxicity of methylated- $\beta$-CDs was the highest on intestinal Caco- 2 cells, while ionic derivatives proved to be less toxic than methylated derivatives. Substitution with hydroxypropyl groups also drastically decreased cytotoxicity. Similar structure-activity relationship was revealed in the case of $\alpha$-cyclodextrins [104]. $\beta$-cyclodextrin-cell membrane interaction decreases the cholesterol content of the membranes, causing the altered function of the cell membrane and can disrupt the barrier function of cell layers. $10 \mathrm{mM}$ methyl-beta-cyclodextrin lowered cell cholesterol levels by $40 \%$, increased the transepithelial electric resistance (TEER) and paracellular permeability of dextrans through Caco-2 cell layers [105]. It was found, that cholesterol extraction caused the destabilization of tight-junction protein complexes, which are localized in lipid rafts. On the other hand, cholesterol extraction can decrease the function of efflux transporters, which have important role in the complex intestinal barrier systems. Several members of $\mathrm{ABC}$ transporters (ATP-binding cassette transporters) can be found in the intestinal membrane. These transporters decrease the absorption of their drug substrates by pumping them back to the intestinal lumen [106]. The effect of cholesterol and the membrane microenvironment on the ABC transporter P-glycoprotein (Pgp) function was widely studied. There is a complex interplay between Pgp and the membrane microenvironment, cholesterol-rich microdomains may modulate its function [107] and conformation [108] and cholesterol depletion can inhibit its function [109]. Dimethyl- $\beta$-cyclodextrin enhanced both the oral bioavailability of tacrolimus in rats and its permeability on Caco-2 cells by Pgp inhibition [110]. Randomly methylated $\beta$-cyclodextrin derivatives can enhance taxol permeability through human intestinal epithelial Caco-2 cell monolayer without Pgp inhibition as we showed earlier [111] and another mechanism, the endocytosis can be one of the mechanism, which can contribute the enhanced cellular uptake of paclitaxel [112].

In the recent years complexation of cholesterol by cyclodextrins is also utilized in the treatment of a rare cholesterol storage disorder, Niemann Pick Disease Type C (NPC). In this disease the normal intracellular cholesterol trafficking is inhibited because of the mutation of NPC1 or NPC2 genes resulting the unesterified cholesterol accumulation in lysosomes/late endosomes. The disease has broad clinical spectrum ranging from a neonatal fatal disorder to an adult-onset chronic neurodegenerative disease with cholesterol accumulation in brain, liver and spleen [113]. Interestingly hydroxypropyl- $\beta$-cyclodextrin (HPBCD) was found to be effective in vitro in NPC mutant cells [114] and endocytosis of the cyclodextrins was found to be responsible for cellular cholesterol reduction [115]. The effectiveness of subcutaneous (sc) or intraperitoneal (ip) administration of HPBCD was proved in $\mathrm{Npc}^{-/-}$and $\mathrm{Npc}^{-/-}$mice, it reduced intraneuronal storage, and significantly increased the lifespan of the animals. The beneficial effects of HPBCD on CNS neurons in NPC1 mouse model was shown, however the mechanism by which these effects were facilitated was unknown [116]. It is known, that HPBCD permeability is very low on the blood-brain barrier and does not accumulates in the brain [117]. However, HPBCD interact with the endothelium of the cerebral vasculature and may help the clearance of cholesterol from the CNS [118]. This example clearly shows the complexity of cyclodextrin's effect on biological barriers in pathological conditions related to cholesterol dyshomeostasis. Earlier studies showed, that i.v. administration of HPBCD is safe and well tolerated $[119,120]$ and recently HPBCD was approved as an orphan drug for the treatment of NPC. Intrathecal HPBCD was subjected to clinical trial to reduce cholesterol accumulation and slow the disease progression with an acceptable safety profile [121]. HPBCD slowed the disease progression, but an expected adverse event, ototoxicity and hearing loss was recorded in all patients. No other drug-related serious adverse events were observed [121]. New cyclodextrin derivatives like 6-O- $\alpha$-Maltosyl- $\beta$-Cyclodextrin [122] or polyrotaxane-based delivery systems [123] are also developed to improve the efficacy of the treatment. Not just hydroxypropyl- $\beta$-cyclodextrin but also hydroxypropyl- $\gamma$-cyclodextrin can be efficient in case of cholesterol accumulation defect. Latter has no ability to complex cholesterol, that is why there should be another mechanism to explain this phenomenon. It was supposed that cyclodextrins can induce cellular signaling routes to facilitate 
intracellular cholesterol trafficking [124,125]. To achieve the above-mentioned effects, HPBCD molecule must enter the cells. Due to its hydrophilic character, big molecular mass, the low octanol/water partition coefficient and the number of hydrogen bond donors and acceptors it is not able to permeate the cell membrane by passive diffusion [93]. The only possibility to enter the cells is the endocytosis. To understand the cellular internalization of cyclodextrins a brief summary of endocytic pathways is required.

\section{Endocytosis of Cyclodextrins}

Endocytosis is one of the most important capability of a cell. It controls the composition of plasma membrane and supports the communication between the cell and its environment. Many endocytic pathways can be differentiated in mammalian cells according to their dependencies on lipids and proteins [126].

Phagocytosis and pinocytosis can be differentiated by the content of the vesicle. Primarily professional phagocytes (macrophages, neutrophiles, monocytes, and dendritic cells) can take up larger (opsonized) particles by phagocytosis, while pinocytosis (when cells internalize fluid) can be found in all kinds of mammalian cell. The most recent classification of pinocytic pathways is the following: Clathrin dependent endocytosis, caveolae dependent endocytosis, micropinocytosis, and clathrin and caveolae independent endocytosis.

The diameter of phagosomes and macropinosomes is around 0.2-10 micrometers, in other cases vesicles are smaller [127]. After moving into the cytosol, vesicles fuse with lysosomes in case of phagocytosis, macropinocytosis and clathrin dependent endocytosis [128,129].

One of the most understood and studied pathway is clathrin dependent endocytosis. In case of clathrin dependent endocytosis, the cargo is adsorbed by plasma membrane proteins and a clathrin coated pit is formed, then the pit changes to a clathrin coated vesicle. On the surface of many mammalian cells (mainly on smooth muscle, type I pneumocytes, fibroblasts, adipocytes and endothelial cells) nonclathrin-coated plasma membrane buds (known as caveolae) can be observed. These are flask-shaped invaginations with a diameter of 60-80 nm. Macropinosomes can be formed usually from highly ruffled regions of the plasma membrane. In this case extracellular fluid is internalized, and larger membrane area is involved than in case of clathrin-or caveolae dependent endocytosis. Macropinocytosis is a nonselective form of endocytosis and a cholesterol dependent process [126].

In the last few years greater interest focused on the possibility of endocytosis of cyclodextrins (and their complexes). Importance of this mechanism could be negligible in case of small, lipophilic molecules, which penetrates easily and quickly through the barrier membrane. On the other hand, the invagination of the plasma membrane and the formation of endocytic vesicles can increase the available membrane surface for cyclodextrin complex-membrane interaction. As it is a dynamic process, its impact on drug absorption through the gastrointestinal tract should be considered. For bigger molecules, such as peptides or oligonucleotides, endocytosis can be an important route to overcome cell membrane. Endocytosis of fluorescently labelled $\beta$-cyclodextrin derivatives was confirmed in different cell types. Fluorescein-, and rhodamine-labelled random methyl-beta-cyclodextrin, fluorescein-labelled hydroxypropyl-beta cyclodextrin and soluble beta-cyclodextrin polymer were tested on human intestinal epithelial Caco-2 cells [112,130]. Fluorescein-labelled methyl-beta-cyclodextrin was tested on HeLa cells [131], methyl-beta-cyclodextrin-dextran-AlexaFluor546 polymer was studied on NPC mutant human fibroblasts [115], while mono-4-(N-6-deoxy-6-amino- $\beta$-cyclodextrin)-7-nitrobenzofuran was examined on HepG2 and SK-MEL-24 cells [132]. On Caco-2 cells macropynocytosis, while on HeLa cells clathrin-dependent endocytosis was found to be responsible for the endocytosis of fluorescein-labelled methyl-beta-cyclodextrin. It may seem contradictory, but in different cell types different mechanisms can function or several mechanisms may work to varying degrees. There are no experimental results available about the effect of the fluorophore type or structure-activity 
relationships on the endocytosis, but it seems, that it takes place with different fluorophores and cyclodextrin derivatives.

The endocytosis of functionalized cyclodextrins should be distinguished from the above-mentioned non-specific processes. In this cases, folate-appended methyl- $\beta$-cyclodextrin [133] or mannose-modified $\alpha$-cyclodextrin based polyrotaxanes [17] can be mentioned as examples for receptor-mediated endocytosis through the interaction with folate and mannose receptors respectively.

Recently an interesting effect of cell membrane cholesterol extraction by methyl- $\beta$-cyclodextrins was revealed, which can support the role of endocytosis in drug absorption. Cell membranes are dynamic, fluid structures, having curvature and the membrane lipid bilayers have an asymmetric distribution of lipids between the cytosolic and exofacial leaflets. Anionic phospholipids are primarily situated in the cytosolic leaflet, which may cause the electrostatic repulsion between anionic headgroups inducing membrane curvature. Curvature generation of the membrane depends on its lipid composition and protein-mediated mechanisms. The large amount of membrane cholesterol and its spontaneous flip-flop movement between membrane leaflets is considered to balance the electrostatic repulsion and the resulting membrane curvature. However, membrane cholesterol extraction causes the great increase in the negative surface charge density on the inner membrane leaflet, promoting the generation of spontaneous positive curvature and rapid membrane internalization [134]. In this sense cyclodextrins can be considered as nonspecific membrane internalization inducers on biological barriers by cholesterol extraction, causing the internalization of the fluid in its proximity, which may contribute to the drug absorption. However, it should be also noted, that decreasing membrane cholesterol with cyclodextrins at high concentrations, results decreased endocytic processes $[135,136]$ and enhanced exocytosis [137]. The above mentioned cyclodextrin-cell membrane interactions are quite complex and depend on the cyclodextrin type, concentration and the cell types. The effects of cyclodextrins on biological barriers and cell membranes are summarized in Figure 7.

\begin{tabular}{|c|c|c|}
\hline \multicolumn{3}{|c|}{ 1. Transportation of the Complexed Drugs through the Unstirred Water Layer (UWL) } \\
\hline \multirow{3}{*}{$\begin{array}{l}\text { 2. Cholesterol and } \\
\text { lipid complexation }\end{array}$} & \multicolumn{2}{|c|}{ Destabilization of tight-junction protein complexes causes decreased barrier function } \\
\hline & \multicolumn{2}{|c|}{ Decreases the function of efflux $(\mathrm{ABC})$ transporters } \\
\hline & \multicolumn{2}{|c|}{ Nonspecific membrane internalization inducer } \\
\hline \multirow{3}{*}{$\begin{array}{l}\text { 3. Endocytosis of } \\
\text { cyclodextrins }\end{array}$} & Macropinocytosis & \multirow{2}{*}{$\begin{array}{ll}\text { - } & \text { Fluorescent, non-functionalized } \\
\text { cyclodextrins }\end{array}$} \\
\hline & - $\quad$ Clathrin-dependent endocytosis & \\
\hline & - $\quad$ Receptor-mediated endocytosis & $\begin{array}{l}\text { Folate-appended or mannose- } \\
\text { modified functionalized cyclodextrin } \\
\text { derivatives }\end{array}$ \\
\hline
\end{tabular}

Figure 7. Effects of cyclodextrins on biological barriers.

\section{Conclusions}

In summary cyclodextrins are extraordinary molecules, which have several effects on cell membranes and biological barriers, but these effects can be originated in their host-guest interactions with drugs or biomolecules. According to the available data the following mechanisms can be responsible for their drug absorption enhancement on barriers:

- The improvement of water solubility of lipophilic drugs;

- increased permeation of lipophilic molecules through the unstirred water layer (UWL);

- permeabilization of cell membrane by removing cholesterol, which leads to further consequences such as:

- Changes in the function of tight junctions by destabilizing the tight junction proteins localized in lipid rafts, causing increased paracellular permeability and

- inhibition the function of efflux pumps;

- endocytosis of free cyclodextrins; and 
- endocytosis of cyclodextrin-drug complexes.

Among the above-mentioned mechanisms, the solubility and permeability enhancements could be the two major mechanisms for the improvement of drug absorption. According to the Biopharmaceutics Classification System (BCS) solubility and intestinal permeability are two major factors, which govern the rate and extent of drug absorption. Cyclodextrins can be suitable excipients mainly for the improvement of solubility of Class 2 drugs (with low solubility-high permeability) and for the improvement of solubility and intestinal permeability of Class 4 drugs (low solubility-low permeability). On the other hand, effects related to the cell membrane-cyclodextrin interactions cannot be neglected. Destabilization of the tight junction proteins can alter the permeability not just the intestinal, but other barriers and the simultaneous inhibition of the efflux transporters can contribute to the enhanced drug penetration. However, the permeability enhancement on biological barriers could be harmful and cause irreversible damages. The route of endocytosis could be an alternative solution for permeability enhancement. Even if the capacity of endocytosis is limited, it is a continuous and dynamic process on biological barriers, by which the contact surface of cyclodextrin complexes or drug delivery systems and biological membranes could be increased. Developing new cyclodextrin carriers, targeting the endocytic pathway and late endosomes/lysosomes, may help to improve drug penetration through biological barriers. As we discussed cyclodextrins have complex effects on biological barriers which may act simultaneously contributing to the drug absorption and distribution.

Funding: This paper was supported by the János Bolyai Research Scholarship of the Hungarian Academy of Sciences (BO/00290/16), FK_17 (FK124634) research grant of the National Research, Development and Innovation Office, Budapest, Hungary, EFOP-3.6.1-16-2012 and ÚNKP-18-4 New National Excellence Program of the Ministry of Human Capacities (ÚNKP-18-4-DE-99).

Conflicts of Interest: The authors declare no conflict of interest.

\section{References}

1. Szejtli, J. Introduction and General Overview of Cyclodextrin Chemistry. Chem. Rev. 1998, 98, $1743-1754$. [CrossRef] [PubMed]

2. Ikuta, D.; Hirata, Y.; Wakamori, S.; Shimada, H.; Tomabechi, Y.; Kawasaki, Y.; Ikeuchi, K.; Hagimori, T.; Matsumoto, S.; Yamada, H. Conformationally supple glucose monomers enable synthesis of the smallest cyclodextrins. Science 2019, 364, 674-677. [CrossRef] [PubMed]

3. Assaf, K.I.; Gabel, D.; Zimmermann, W.; Nau, W.M. High-affinity host-guest chemistry of large-ring cyclodextrins. Org. Biomol. Chem. 2016, 14, 7702-7706. [CrossRef] [PubMed]

4. Sonnendecker, C.; Thürmann, S.; Przybylski, C.; Zitzmann, F.D.; Heinke, N.; Krauke, Y.; Monks, K.; Robitzki, A.A.; Belder, D.; Zimmermann, W. Large-Ring Cyclodextrins as Chiral Selectors for Enantiomeric Pharmaceuticals. Angew. Chem. Int. Ed. 2019, 58, 6411-6414. [CrossRef] [PubMed]

5. Loftsson, T. Cyclodextrins and the biopharmaceutics classification system of drugs. J. Incl. Phenom. Macrocycl. Chem. 2002, 44, 63-67. [CrossRef]

6. Higuchi, T.; Connors, K.A. Phase solubility techniques. Adv. Anal. Chem. Instrum. 1965, 4, 117-212.

7. Loftsson, T.; Brewster, M.E. Pharmaceutical applications of cyclodextrins: Basic science and product development. J. Pharm. Pharmacol. 2010, 62, 1607-1621. [CrossRef]

8. Loftsson, T.; Magnúsdóttir, A.; Másson, M.; Sigurjónsdóttir, J.F. Self-Association and Cyclodextrin Solubilization of Drugs. J. Pharm. Sci. 2002, 91, 2307-2316. [CrossRef]

9. Coleman, A.W.; Nicolis, I.; Keller, N.; Dalbiez, J.P. Aggregation of cyclodextrins: An explanation of the abnormal solubility of?-cyclodextrin. J. Incl. Phenom. Mol. Recognit. Chem. 1992, 13, 139-143. [CrossRef]

10. Becheri, A.; Lo Nostro, P.; Ninham, B.W.; Baglioni, P. The curious world of polypseudorotaxanes: Cyclodextrins as probes of water structure. J. Phys. Chem. B 2003, 107, 3979-3987. [CrossRef]

11. Harada, A.; Kamachi, M. Complex formation between poly(ethylene glycol) and $\alpha$-cyclodextrin. Macromolecules 1990, 23, 2821-2823. [CrossRef]

12. Harada, A.; Kamachi, M. Complex formation between cyclodextrin and poly(propylene glycol). J. Chem. Soc. Chem. Commun. 1990, 1322-1323. [CrossRef] 
13. Higashi, T.; Hirayama, F.; Misumi, S.; Motoyama, K.; Arima, H.; Uekama, K. Polypseudorotaxane Formation of Randomly-Pegylated Insulin with Cyclodextrins: Slow Release and Resistance to Enzymatic Degradation. Chem. Pharm. Bull. 2009, 57, 541-544. [CrossRef] [PubMed]

14. Chang, J.; Li, Y.; Wang, G.; He, B.; Gu, Z. Fabrication of novel coumarin derivative functionalized polypseudorotaxane micelles for drug delivery. Nanoscale 2013, 5, 813-820. [CrossRef] [PubMed]

15. Harada, A. Cyclodextrin-Based Molecular Machines. Acc. Chem. Res. 2001, 34, 456-464. [CrossRef]

16. Nepogodiev, S.A.; Stoddart, J.F. Cyclodextrin-Based Catenanes and Rotaxanes. Chem. Rev. 1998, 98, 1959-1976. [CrossRef]

17. Shibaguchi, K.; Tamura, A.; Terauchi, M.; Matsumura, M.; Miura, H.; Yui, N. Mannosylated Polyrotaxanes for Increasing Cellular Uptake Efficiency in Macrophages through Receptor-Mediated Endocytosis. Molecules 2019, 24, 439. [CrossRef]

18. Wang, H.; Yin, H.; Yan, F.; Sun, M.; Du, L.; Peng, W.; Li, Q.; Feng, Y.; Zhou, Y. Folate-mediated mitochondrial targeting with doxorubicinpolyrotaxane nanoparticles overcomes multidrug resistance. Oncotarget 2015, 6, 2827.

19. Yu, G.; Yang, Z.; Fu, X.; Yung, B.C.; Yang, J.; Mao, Z.; Shao, L.; Hua, B.; Liu, Y.; Zhang, F.; et al. Polyrotaxane-based supramolecular theranostics. Nat. Commun. 2018, 9, 766. [CrossRef]

20. Dandekar, P.; Jain, R.; Keil, M.; Loretz, B.; Muijs, L.; Schneider, M.; Auerbach, D.; Jung, G.; Lehr, C.M.; Wenz, G. Cellular delivery of polynucleotides by cationic cyclodextrin polyrotaxanes. J. Control. Release 2012, 164, 387-393. [CrossRef]

21. Yang, C.; Wang, X.; Li, H.; Goh, S.H.; Li, J. Synthesis and Characterization of Polyrotaxanes Consisting of Cationic $\alpha$-Cyclodextrins Threaded on Poly[(ethylene oxide)- ran -(propylene oxide)] as Gene Carriers. Biomacromolecules 2007, 8, 3365-3374. [CrossRef] [PubMed]

22. Hattori, K.; Ikeda, H. Modification Reactions of Cyclodextrins and the Chemistry of Modified Cyclodextrins. In Cyclodextrins and Their Complexes; Wiley-VCH Verlag GmbH \& Co. KGaA: Weinheim, Germany, 2006; pp. 31-64. ISBN 3527312803.

23. Krause, R.W.; Mamba, B.B.; Bambo, F.M.; Malefetse, T.J. Cyclodextrin polymers: Synthesis and application in water treatment. In Cyclodextrins: Chemistry Physics; Transworld Research Network: Kerala, India, 2010; pp. 168-194.

24. Mansuri, S.; Kesharwani, P.; Jain, K.; Tekade, R.K.; Jain, N.K. Mucoadhesion: A promising approach in drug delivery system. React. Funct. Polym. 2016, 100, 151-172. [CrossRef]

25. Ijaz, M.; Prantl, M.; Lupo, N.; Laffleur, F.; Hussain Asim, M.; Matuszczak, B.; Bernkop-Schnürch, A. Development of pre-activated $\alpha$-cyclodextrin as a mucoadhesive excipient for intra-vesical drug delivery. Int. J. Pharm. 2017, 534, 339-347. [CrossRef] [PubMed]

26. Ijaz, M.; Matuszczak, B.; Rahmat, D.; Mahmood, A.; Bonengel, S.; Hussain, S.; Huck, C.W.; Bernkop-Schnürch, A. Synthesis and characterization of thiolated $\beta$-cyclodextrin as a novel mucoadhesive excipient for intra-oral drug delivery. Carbohydr. Polym. 2015, 132, 187-195. [CrossRef]

27. Ijaz, M.; Ahmad, M.; Akhtar, N.; Laffleur, F.; Bernkop-Schnürch, A. Thiolated $\alpha$-Cyclodextrin: The Invisible Choice to Prolong Ocular Drug Residence Time. J. Pharm. Sci. 2016, 105, 2848-2854. [CrossRef]

28. Ijaz, M.; Griessinger, J.A.; Mahmood, A.; Laffleur, F.; Bernkop-Schnürch, A. Thiolated Cyclodextrin: Development of a Mucoadhesive Vaginal Delivery System for Acyclovir. J. Pharm. Sci. 2016, 105, 1714-1720. [CrossRef]

29. Asim, M.H.; Moghadam, A.; Ijaz, M.; Mahmood, A.; Götz, R.X.; Matuszczak, B.; Bernkop-Schnürch, A. S-protected thiolated cyclodextrins as mucoadhesive oligomers for drug delivery. J. Colloid Interface Sci. 2018, 531, 261-268. [CrossRef]

30. Venter, J.P.; Kotzé, A.F.; Auzély-Velty, R.; Rinaudo, M. Synthesis and evaluation of the mucoadhesivity of a CD-chitosan derivative. Int. J. Pharm. 2006, 313, 36-42. [CrossRef]

31. Sajomsang, W.; Nuchuchua, O.; Gonil, P.; Saesoo, S.; Sramala, I.; Soottitantawat, A.; Puttipipatkhachorn, S.; Ruktanonchai, U.R. Water-soluble $\beta$-cyclodextrin grafted with chitosan and its inclusion complex as a mucoadhesive eugenol carrier. Carbohydr. Polym. 2012, 89, 623-631. [CrossRef]

32. Sajomsang, W.; Gonil, P.; Ruktanonchai, U.R.; Pimpha, N.; Sramala, I.; Nuchuchua, O.; Saesoo, S.; Chaleawlert-umpon, S.; Puttipipatkhachorn, S. Self-aggregates formation and mucoadhesive property of water-soluble $\beta$-cyclodextrin grafted with chitosan. Int. J. Biol. Macromol. 2011, 48, 589-595. [CrossRef] 
33. Wang, J.; Zong, J.Y.; Zhao, D.; Zhuo, R.X.; Cheng, S.X. In situ formation of chitosan-cyclodextrin nanospheres for drug delivery. Colloids Surf. B Biointerfaces 2011, 87, 198-202. [CrossRef]

34. Gomez, C.G.; Chambat, G.; Heyraud, A.; Villar, M.; Auzély-Velty, R. Synthesis and characterization of a $\beta$-CD-alginate conjugate. Polymer 2006, 47, 8509-8516. [CrossRef]

35. Pluemsab, W.; Sakairi, N.; Furuike, T. Synthesis and inclusion property of $\alpha$-cyclodextrin-linked alginate. Polymer 2005, 46, 9778-9783. [CrossRef]

36. Parmar, V.; Patel, G.; Abu-Thabit, N.Y. Responsive Cyclodextrins as Polymeric Carriers for Drug Delivery Applications; Elsevier Ltd.: Amsterdam, The Netherlands, 2018; ISBN 9780081019979.

37. Schmaljohann, D. Thermo- and pH-responsive polymers in drug delivery. Adv. Drug Deliv. Rev. 2006, 58, 1655-1670. [CrossRef]

38. Wang, Y.; Yang, N.; Wang, D.; He, Y.; Chen, L.; Zhao, Y. Poly (MAH- $\beta$-cyclodextrin-co-NIPAAm) hydrogels with drug hosting and thermo/pH-sensitive for controlled drug release. Polym. Degrad. Stab. 2018, 147, 123-131. [CrossRef]

39. Zhou, Z.; Li, G.; Wang, N.; Guo, F.; Guo, L.; Liu, X. Synthesis of temperature/pH dual-sensitive supramolecular micelles from $\beta$-cyclodextrin-poly( $N$-isopropylacrylamide) star polymer for drug delivery. Colloids Surf. B Biointerfaces 2018, 172, 136-142. [CrossRef]

40. Liu, L.; Feng, X.; Pei, Y.; Wang, J.; Ding, J.; Chen, L. $\alpha$-Cyclodextrin concentration-controlled thermo-sensitive supramolecular hydrogels. Mater. Sci. Eng. C 2018, 82, 25-28. [CrossRef]

41. Danhier, F.; Feron, O.; Préat, V. To exploit the tumor microenvironment: Passive and active tumor targeting of nanocarriers for anti-cancer drug delivery. J. Control. Release 2010, 148, 135-146. [CrossRef]

42. Zhang, D.; Lv, P.; Zhou, C.; Zhao, Y.; Liao, X.; Yang, B. Cyclodextrin-based delivery systems for cancer treatment. Mater. Sci. Eng. C 2019, 96, 872-886. [CrossRef]

43. Peng, L.; Liu, S.; Feng, A.; Yuan, J. Polymeric Nanocarriers Based on Cyclodextrins for Drug Delivery: Host-Guest Interaction as Stimuli Responsive Linker. Mol. Pharm. 2017, 14, 2475-2486. [CrossRef]

44. Hao, W.; Liu, D.; Wang, Y.; Han, X.; Xu, S.; Liu, H. Dual-stimuli responsive nanoparticles (UCNP-CD@APP) assembled by host-guest interaction for drug delivery. Colloids Surf. A Physicochem. Eng. Asp. 2018, 537, 446-451. [CrossRef]

45. Chen, X.; Wang, Y.; Rong, R.; Zhao, C.; Li, X.; Wang, K. Synthesis, thermo-responsive behavior of cyclodextrin modi fi ed Bi-perylene monoimide derivative. Dye. Pigment. 2019, 160, 779-786. [CrossRef]

46. Zhou, H.Y.; Wang, Z.Y.; Duan, X.Y.; Jiang, L.J.; Cao, P.P.; Li, J.B.J.X.; Li, J.B.J.X.; Wang, J.J.; Guo, Z.; Xiong, J.; et al. Facile synthesis of chitosan-grafted beta-cyclodextrin for stimuli-responsive drug delivery. Int. J. Biol. Macromol. 2019, 125, 941-947.

47. Borandeh, S.; Abdolmaleki, A.; Abolmaali, S.S.; Tamaddon, A.M. Synthesis, structural and in-vitro characterization of $\$ \beta \$$-cyclodextrin grafted L-phenylalanine functionalized graphene oxide nanocomposite: A versatile nanocarrier for $\mathrm{pH}$-sensitive doxorubicin delivery. Carbohydr. Polym. 2018, 201, 151-161. [CrossRef]

48. Sawant, V.J.; Bamane, S.R. PEG-beta-cyclodextrin functionalized zinc oxide nanoparticles show cell imaging with high drug payload and sustained $\mathrm{pH}$ responsive delivery of curcumin in to MCF-7 cells. J. Drug Deliv. Sci. Technol. 2018, 43, 397-408. [CrossRef]

49. Zhang, M.; Wang, J.; Jin, Z. Supramolecular hydrogel formation between chitosan and hydroxypropyl $\$ \beta \$-$ cyclodextrin via Diels-Alder reaction and its drug delivery. Int. J. Biol. Macromol. 2018, 114, 381-391. [CrossRef]

50. Yang, Z.; Peng, Y.; Qiu, L. pH-Responsive supramolecular micelle based on host-guest interaction of poly( $\beta$-amino ester) derivatives and adamantyl-terminated poly(ethylene glycol) for cancer inhibition. Chin. Chem. Lett. 2018, 29, 1839-1844. [CrossRef]

51. Zhang, Y.; Yang, D.; Chen, H.; Lim, W.Q.; Phua, F.S.Z.; An, G.; Yang, P.; Zhao, Y. Reduction-sensitive fluorescence enhanced polymeric prodrug nanoparticles for combinational photothermal-chemotherapy. Biomaterials 2018, 163, 14-24. [CrossRef]

52. Morin-Crini, N.; Winterton, P.; Fourmentin, S.; Wilson, L.D.; Fenyvesi, É.; Crini, G. Water-insoluble $\beta$-cyclodextrin-epichlorohydrin polymers for removal of pollutants from aqueous solutions by sorption processes using batch studies: A review of inclusion mechanisms. Prog. Polym. Sci. 2018, 78, 1-23. [CrossRef]

53. József, S. Cyclodextrins and Their Inclusion Complexes; Akadémiai Kiadó: Budapest, Hungary, 1982; ISBN 963 0528509. 
54. Rossi, B.; Fontana, A.; Giarola, M.; Mariotto, G.; Mele, A.; Punta, C.; Melone, L.; Toraldo, F.; Trotta, F. Glass-like dynamics of new cross-linked polymeric systems: Behavior of the Boson peak. J. Non. Cryst. Solids 2014, 401, 73-77. [CrossRef]

55. Gidwani, B.; Vyas, A. Synthesis, characterization and application of Epichlorohydrin- $\beta$-cyclodextrin polymer. Colloids Surf. B Biointerfaces 2014, 114, 130-137. [CrossRef]

56. Garcia-Fernandez, M.J.; Tabary, N.; Chai, F.; Cazaux, F.; Blanchemain, N.; Flament, M.P.; Martel, B. New multifunctional pharmaceutical excipient in tablet formulation based on citric acid-cyclodextrin polymer. Int. J. Pharm. 2016, 511, 913-920. [CrossRef]

57. Huang, W.; Hu, Y.; Li, Y.; Zhou, Y.; Niu, D.; Lei, Z.; Zhang, Z. Citric acid-crosslinked $\beta$-cyclodextrin for simultaneous removal of bisphenol A, methylene blue and copper: The roles of cavity and surface functional groups. J. Taiwan Inst. Chem. Eng. 2018, 82, 189-197. [CrossRef]

58. Nojavan, S.; Yazdanpanah, M. Micro-solid phase extraction of benzene, toluene, ethylbenzene and xylenes from aqueous solutions using water-insoluble $\beta$-cyclodextrin polymer as sorbent. J. Chromatogr. A 2017, 1525, 51-59. [CrossRef]

59. Morin-Crini, N.; Crini, G. Environmental applications of water-insoluble $\beta$-cyclodextrin- epichlorohydrin polymers. Prog. Polym. Sci. 2013, 38, 344-368. [CrossRef]

60. Moulahcene, L.; Skiba, M.; Senhadji, O.; Milon, N.; Benamor, M.; Lahiani-Skiba, M. Inclusion and removal of pharmaceutical residues from aqueous solution using water-insoluble cyclodextrin polymers. Chem. Eng. Res. Des. 2015, 97, 145-158. [CrossRef]

61. Tang, P.; Sun, Q.; Zhao, L.; Tang, Y.; Liu, Y.; Pu, H.; Gan, N.; Liu, Y.; Li, H. A simple and green method to construct cyclodextrin polymer for the effective and simultaneous estrogen pollutant and metal removal. Chem. Eng. J. 2019, 366, 598-607. [CrossRef]

62. Sherje, A.P.; Dravyakar, B.R.; Kadam, D.; Jadhav, M. Cyclodextrin-based nanosponges: A critical review. Carbohydr. Polym. 2017, 173, 37-49. [CrossRef]

63. Caldera, F.; Tannous, M.; Cavalli, R.; Zanetti, M.; Trotta, F. Evolution of Cyclodextrin Nanosponges. Int. J. Pharm. 2017, 531, 470-479. [CrossRef]

64. Cavalli, R.; Trotta, F.; Tumiatti, W. Cyclodextrin-based Nanosponges for Drug Delivery. J. Incl. Phenom. Macrocycl. Chem. 2006, 56, 209-213. [CrossRef]

65. Darandale, S.S.; Vavia, P.R. Cyclodextrin-based nanosponges of curcumin: Formulation and physicochemical characterization. J. Incl. Phenom. Macrocycl. Chem. 2013, 75, 315-322. [CrossRef]

66. Li, D.; Ma, M. Nanosponges for water purification. Clean Prod. Process. 2000, 2, 112-116. [CrossRef]

67. Gabr, M.M.; Mortada, S.M.; Sallam, M.A. Carboxylate cross-linked cyclodextrin: A nanoporous scaffold for enhancement of rosuvastatin oral bioavailability. Eur. J. Pharm. Sci. 2018, 111, 1-12. [CrossRef] [PubMed]

68. Argenziano, M.; Haimhoffer, A.; Bastiancich, C.; Caldera, F.; Trotta, F.; Scutera, S.; Alotto, D.; Fumagalli, M.; Musso, T.; Castagnoli, C.; et al. In Vitro Enhanced Skin Permeation and Retention of Imiquimod Loaded in $\beta$ -Cyclodextrin Nanosponge Hydrogel. Pharmaceutics 2019, 11, 138. [CrossRef]

69. Pushpalatha, R.; Selvamuthukumar, S.; Kilimozhi, D. Cyclodextrin-based nanosponges for curcumin delivery-Physicochemical characterization, drug release, stability and cytotoxicity. J. Drug Deliv. Sci. Technol. 2018, 45, 45-53. [CrossRef]

70. Ansari, K.A.; Vavia, P.R.; Trotta, F.; Cavalli, R. Cyclodextrin-Based Nanosponges for Delivery of Resveratrol: In Vitro Characterisation, Stability, Cytotoxicity and Permeation Study. Aaps Pharmscitech 2011, 12, 279-286. [CrossRef]

71. Zohrehvand, S.; Evans, C.H. 2-Naphthol-containing $\beta$-cyclodextrin-epichlorohydrin copolymers: Synthesis, characterization and fluorescence studies. Polym. Int. 2005, 54, 744-753. [CrossRef]

72. Lembo, D.; Swaminathan, S.; Donalisio, M.; Civra, A.; Pastero, L.; Aquilano, D.; Vavia, P.; Trotta, F.; Cavalli, R. Encapsulation of Acyclovir in new carboxylated cyclodextrin-based nanosponges improves the agent's antiviral efficacy. Int. J. Pharm. 2013, 443, 262-272. [CrossRef]

73. Ncube, P.; Krause, R.W.M.; Mamba, B.B. Detection of chloroform in water using an azo dye-modified $\beta$-cyclodextrin-Epichlorohydrin copolymer as a fluorescent probe. Phys. Chem. Earth Parts A/B/C 2014, 67-69, 79-85. [CrossRef]

74. Wajs, E.; Caldera, F.; Trotta, F.; Fragoso, A. Peroxidase-encapsulated cyclodextrin nanosponge immunoconjugates as a signal enhancement tool in optical and electrochemical assays. Analyst 2014, 139, 375-380. [CrossRef] 
75. Fenyvesi, É.; Ujházy, A.; Szejtli, J.; Potter, S.; Gan, T.G. Controlled release of drugs from CD polymers substituted with ionic groups. J. Incl. Phenom. Mol. Recognit. Chem. 1996, 25, 185-189. [CrossRef]

76. Daga, M.; Ulllio, C.; Argenziano, M.; Dianzani, C.; Cavalli, R.; Trotta, F.; Ferretti, C.; Zara, G.P.; Gigliotti, C.L.; Ciamporcero, E.S.; et al. GSH-targeted nanosponges increase doxorubicin-induced toxicity "in vitro" and "in vivo" in cancer cells with high antioxidant defenses. Free Radic. Biol. Med. 2016, 97, 24-37. [CrossRef]

77. Argenziano, M.; Lombardi, C.; Ferrara, B.; Trotta, F.; Caldera, F.; Blangetti, M.; Koltai, H.; Kapulnik, Y.; Yarden, R.; Gigliotti, L.; et al. Glutathione/pH-responsive nanosponges enhance strigolactone delivery to prostate cancer cells. Oncotarget 2018, 9, 35813. [CrossRef]

78. Gooding, M.; Malhotra, M.; McCarthy, D.J.; Godinho, B.M.D.C.; Cryan, J.F.; Darcy, R.; O'Driscoll, C.M. Synthesis and characterization of rabies virus glycoprotein-tagged amphiphilic cyclodextrins for siRNA delivery in human glioblastoma cells: In vitro analysis. Eur. J. Pharm. Sci. 2015, 71, 80-92. [CrossRef]

79. Russo, M.; Saladino, M.L.; Chillura Martino, D.; Lo Meo, P.; Noto, R. Polyaminocyclodextrin nanosponges: Synthesis, characterization and pH-responsive sequestration abilities. RSC Adv. 2016, 6, 49941-49953. [CrossRef]

80. Trotta, F.; Caldera, F.; Cavalli, R.; Soster, M.; Riedo, C.; Biasizzo, M.; Uccello Barretta, G.; Balzano, F.; Brunella, V. Molecularly imprinted cyclodextrin nanosponges for the controlled delivery of L-DOPA: Perspectives for the treatment of Parkinson's disease. Expert Opin. Drug Deliv. 2016, 13, 1671-1680. [CrossRef]

81. Deshmukh, K.; Tanwar, Y.S.; Shende, P.; Cavalli, R. Biomimetic estimation of glucose using non-molecular and molecular imprinted polymer nanosponges. Int. J. Pharm. 2015, 494, 244-248. [CrossRef]

82. Varan, G.; Varan, C.; Erdoğar, N.; Hıncal, A.A.; Bilensoy, E. Amphiphilic cyclodextrin nanoparticles. Int. J. Pharm. 2017, 531, 457-469. [CrossRef]

83. Roux, M.; Perly, B.; Djedaïni-Pilard, F. Self-assemblies of amphiphilic cyclodextrins. Eur. Biophys. J. 2007, 36, 861-867. [CrossRef]

84. Donohue, R.; Mazzaglia, A.; Ravoo, B.J.; Darcy, R. Cationic $\beta$-cyclodextrin bilayer vesicles. Chem. Commun. 2002, 23, 2864-2865. [CrossRef]

85. Sallas, F.; Darcy, R. Amphiphilic cyclodextrins-Advances in synthesis and supramolecular chemistry. Eur. J. Org. Chem. 2008, 2008, 957-969. [CrossRef]

86. Ghera, B.B.; Perret, F.; Chevalier, Y.; Parrot-Lopez, H. Novel nanoparticles made from amphiphilic perfluoroalkyl $\alpha$-cyclodextrin derivatives: Preparation, characterization and application to the transport of acyclovir. Int. J. Pharm. 2009, 375, 155-162. [CrossRef] [PubMed]

87. Nacereddine, A.; Bollacke, A.; Róka, E.; Marminon, C.; Bouaziz, Z.; Fenyvesi, F.; Katalin Bácskay, I.; Jose, J.; Perret, F.; Le Borgne, M. Self-assembled supramolecular nanoparticles improve the cytotoxic efficacy of CK2 inhibitor THN7. Pharmaceuticals 2018, 11, 10. [CrossRef] [PubMed]

88. Godinho, B.M.D.C.; Ogier, J.R.; Quinlan, A.; Darcy, R.; Griffin, B.T.; Cryan, J.F.; O’Driscoll, C.M. PEGylated cyclodextrins as novel siRNA nanosystems: Correlations between polyethylene glycol length and nanoparticle stability. Int. J. Pharm. 2014, 473, 105-112. [CrossRef] [PubMed]

89. McMahon, A.; O’Neill, M.J.; Gomez, E.; Donohue, R.; Forde, D.; Darcy, R.; O’Driscoll, C.M. Targeted gene delivery to hepatocytes with galactosylated amphiphilic cyclodextrins. J. Pharm. Pharmacol. 2012, 64, 1063-1073. [CrossRef] [PubMed]

90. Zagami, R.; Rapozzi, V.; Piperno, A.; Scala, A.; Triolo, C.; Trapani, M.; Xodo, L.E.; Monsù Scolaro, L.; Mazzaglia, A. Folate-Decorated Amphiphilic Cyclodextrins as Cell-Targeted Nanophototherapeutics. Biomacromolecules 2019, 20, 2530-2544. [CrossRef] [PubMed]

91. Lennernaäs, H. Human Intestinal Permeability. J. Pharm. Sci. 1998, 87, 403-410. [CrossRef]

92. Brewster, M.E.; Noppe, M.; Peeters, J.; Loftsson, T. Effect of the unstirred water layer on permeability enhancement by hydrophilic cyclodextrins. Int. J. Pharm. 2007, 342, 250-253. [CrossRef]

93. Loftsson, T.; Vogensen, S.B.; Brewster, M.E.; Konráosdóttir, F. Effects of cyclodextrins on drug delivery through biological membranes. J. Pharm. Sci. 2007, 96, 2532-2546. [CrossRef]

94. Másson, M.; Loftsson, T.; Másson, G.; Stefánsson, E. Cyclodextrins as permeation enhancers: Some theoretical evaluations and in vitro testing. J. Control. Release 1999, 59, 107-118. [CrossRef]

95. Ren, B.; Gao, H.; Cao, Y.; Jia, L. In Silico understanding of the cyclodextrin-phenanthrene hybrid assemblies in both aqueous medium and bacterial membranes. J. Hazard. Mater. 2015, 285, 148-156. [CrossRef] 
96. Erdoğar, N.; Bilensoy, E. Cyclodextrins in drug delivery. In Nanotechnology and Drug Delivery: Volume 1: Nanoplatforms in Drug Delivery; CRC Press: Boca Raton, FL, USA, 2014; Volume 2, pp. 178-209. ISBN 9781466599482.

97. Krause, M.R.; Regen, S.L. The Structural Role of Cholesterol in Cell Membranes: From Condensed Bilayers to Lipid Rafts. Acc. Chem. Res. 2014, 47, 3512-3521. [CrossRef] [PubMed]

98. Fauvelle, F.; Debouzy, J.C.; Crouzy, S.; Göschl, M.; Chapron, Y. Mechanism of $\alpha$-Cyclodextrin-lnduced Hemolysis. 1. The Two-Step Extraction of Phosphatidylinositol from the Membrane. J. Pharm. Sci. 1997, 86, 935-943. [CrossRef] [PubMed]

99. Debouzy, J.C.; Fauvelle, F.; Crouzy, S.; Girault, L.; Chapron, Y.; Göschl, M.; Gadelle, A. Mechanism of $\alpha$-Cyclodextrin Induced Hemolysis. 2. A Study of the Factors Controlling the Association with Serine-, Ethanolamine-, and Choline-Phospholipids. J. Pharm. Sci. 1998, 87, 59-66. [CrossRef] [PubMed]

100. Kilsdonk, E.P.C.; Yancey, P.G.; Stoudt, G.W.; Bangerter, F.W.; Johnson, W.J.; Phillips, M.C.; Rothblat, G.H. Cellular Cholesterol Efflux Mediated by Cyclodextrins. J. Biol. Chem. 1995, 270, 17250-17256. [CrossRef]

101. Monnaert, V.; Tilloy, S.; Bricout, H.; Cecchelli, R.; Monflier, E. Behavior of alpha-, beta-, and gammacyclodextrins and Their Derivatives on an in Vitro Model of Blood-Brain Barrier. J. Pharmacol. Exp. Ther. 2004, 310, 745-751. [CrossRef]

102. Ohtani, Y.; Irie, T.; Uekama, K.; Fukunaga, K.; Pitha, J. Differential effects of alpha-, beta- and gamma-cyclodextrins on human erythrocytes. Eur. J. Biochem. 1989, 186, 17-22. [CrossRef]

103. Kiss, T.; Fenyvesi, F.; Bácskay, I.; Váradi, J.; Fenyvesi, É.; Iványi, R.; Szente, L.; Tósaki, Á.; Vecsernyés, M. Evaluation of the cytotoxicity of $\beta$-cyclodextrin derivatives: Evidence for the role of cholesterol extraction. Eur. J. Pharm. Sci. 2010, 40, 376-380. [CrossRef]

104. Róka, E.; Ujhelyi, Z.; Deli, M.; Bocsik, A.; Fenyvesi, É; Szente, L.; Fenyvesi, F.; Vecsernyés, M.; Váradi, J.; Fehér, P.; et al. Evaluation of the Cytotoxicity of $\alpha$-Cyclodextrin Derivatives on the Caco-2 Cell Line and Human Erythrocytes. Molecules 2015, 20, 20269-20285. [CrossRef]

105. Lambert, D.; O'Neill, C.A.; Padfield, P.J. Depletion of Caco-2 cell cholesterol disrupts barrier function by altering the detergent solubility and distribution of specific tight-junction proteins. Biochem. J. 2005, 387, 553-560. [CrossRef]

106. Chan, L.M.S.; Lowes, S.; Hirst, B.H. The ABCs of drug transport in intestine and liver: Efflux proteins limiting drug absorption and bioavailability. Eur. J. Pharm. Sci. 2004, 21, 25-51. [CrossRef] [PubMed]

107. Sharom, F.J. Complex Interplay between the P-Glycoprotein Multidrug Efflux Pump and the Membrane: Its Role in Modulating Protein Function. Front. Oncol. 2014, 4, 41. [CrossRef] [PubMed]

108. Gutay-Tóth, Z.; Fenyvesi, F.; Bársony, O.; Szente, L.; Goda, K.; Szabó, G.; Bacsó, Z. Cholesterol-dependent conformational changes of P-glycoprotein are detected by the 15D3 monoclonal antibody. Biochim. Biophys. Acta Mol. Cell Biol. Lipids 2016, 1861, 188-195. [CrossRef] [PubMed]

109. Fenyvesi, F.; Fenyvesi, É.; Szente, L.; Goda, K.; Bacsó, Z.; Bácskay, I.; Váradi, J.; Kiss, T.; Molnár, É.; Janáky, T.; et al. P-glycoprotein inhibition by membrane cholesterol modulation. Eur. J. Pharm. Sci. 2008, 34, 236-242. [CrossRef]

110. Arima, H.; Yunomae, K.; Hirayama, F.; Uekama, K. Contribution of P-glycoprotein to the enhancing effects of dimethyl-beta-cyclodextrin on oral bioavailability of tacrolimus. J. Pharmacol. Exp. Ther. 2001, 297, 547-555. [PubMed]

111. Fenyvesi, F.; Kiss, T.; Fenyvesi, É.; Szente, L.; Veszelka, S.; Deli, M.A.; Váradi, J.; Fehér, P.; Ujhelyi, Z.; Tósaki, Á.; et al. Randomly methylated $\beta$-cyclodextrin derivatives enhance taxol permeability through human intestinal epithelial Caco-2 cell monolayer. J. Pharm. Sci. 2011, 100, 4734-4744. [CrossRef]

112. Réti-Nagy, K.; Malanga, M.; Fenyvesi, É.; Szente, L.; Vámosi, G.; Váradi, J.; Bácskay, I.; Fehér, P.; Ujhelyi, Z.; Róka, E.; et al. Endocytosis of fluorescent cyclodextrins by intestinal Caco-2 cells and its role in paclitaxel drug delivery. Int. J. Pharm. 2015, 496, 509-517. [CrossRef]

113. Vanier, M.; Millat, G. Niemann-Pick disease type C. Clin. Genet. 2003, 64, 269-281. [CrossRef]

114. Abi-Mosleh, L.; Infante, R.E.; Radhakrishnan, A.; Goldstein, J.L.; Brown, M.S. Cyclodextrin overcomes deficient lysosome-to-endoplasmic reticulum transport of cholesterol in Niemann-Pick type C cells. Proc. Natl. Acad. Sci. USA 2009, 106, 19316-19321. [CrossRef]

115. Rosenbaum, A.I.; Zhang, G.; Warren, J.D.; Maxfield, F.R. Endocytosis of beta-cyclodextrins is responsible for cholesterol reduction in Niemann-Pick type C mutant cells. Proc. Natl. Acad. Sci. USA 2010, 107, 5477-5482. [CrossRef] 
116. Davidson, C.D.; Ali, N.F.; Micsenyi, M.C.; Stephney, G.; Renault, S.; Dobrenis, K.; Ory, D.S.; Vanier, M.T.; Walkley, S.U. Chronic Cyclodextrin Treatment of Murine Niemann-Pick C Disease Ameliorates Neuronal Cholesterol and Glycosphingolipid Storage and Disease Progression. PLoS ONE 2009, 4, e6951. [CrossRef] [PubMed]

117. Hajdu, I.; Angyal, J.; Szikra, D.; Kertész, I.; Malanga, M.; Fenyvesi, É.; Szente, L.; Vecsernyés, M.; Bácskay, I.; Váradi, J.; et al. Radiochemical synthesis and preclinical evaluation of 68Ga-labeled NODAGA-hydroxypropyl-beta-cyclodextrin (68Ga-NODAGA-HPBCD). Eur. J. Pharm. Sci. 2019, 128, 202-208. [CrossRef] [PubMed]

118. Pontikis, C.C.; Davidson, C.D.; Walkley, S.U.; Platt, F.M.; Begley, D.J. Cyclodextrin alleviates neuronal storage of cholesterol in Niemann-Pick $C$ disease without evidence of detectable blood-brain barrier permeability. J. Inherit. Metab. Dis. 2013, 36, 491-498. [CrossRef] [PubMed]

119. Gould, S.; Scott, R.C. 2-Hydroxypropyl-b-cyclodextrin (HP-b-CD): A toxicology review. Food Chem. Toxicol. 2005, 43, 1451-1459. [CrossRef] [PubMed]

120. Stella, V.J.; He, Q. Cyclodextrins. Toxicol. Pathol. 2008, 36, 30-42. [CrossRef] [PubMed]

121. Ory, D.S.; Ottinger, E.A.; Farhat, N.Y.; King, K.A.; Jiang, X.; Weissfeld, L.; Berry-Kravis, E.; Davidson, C.D.; Bianconi, S.; Keener, L.A.; et al. Intrathecal 2-hydroxypropyl- $\beta$-cyclodextrin decreases neurological disease progression in Niemann-Pick disease, type C1: A non-randomised, open-label, phase 1-2 trial. Lancet 2017, 390, 1758-1768. [CrossRef]

122. Yasmin, N.; Ishitsuka, Y.; Fukaura, M.; Yamada, Y.; Nakahara, S.; Ishii, A.; Kondo, Y.; Takeo, T.; Nakagata, N.; Motoyama, K.; et al. In Vitro and In Vivo Evaluation of 6-O- $\alpha$-Maltosyl- $\beta$-Cyclodextrin as a Potential Therapeutic Agent Against Niemann-Pick Disease Type C. Int. J. Mol. Sci. 2019, 20, 1152. [CrossRef]

123. Tamura, A.; Yui, N. Polyrotaxane-based systemic delivery of $\beta$-cyclodextrins for potentiating therapeutic efficacy in a mouse model of Niemann-Pick type C disease. J. Control. Release 2018, 269, 148-158. [CrossRef]

124. Soga, M.; Ishitsuka, Y.; Hamasaki, M.; Yoneda, K.; Furuya, H.; Matsuo, M.; Ihn, H.; Fusaki, N.; Nakamura, K.; Nakagata, N.; et al. HPGCD Outperforms HPBCD as a Potential Treatment for Niemann-Pick Disease Type C During Disease Modeling with iPS Cells. Stem Cells 2015, 33, 1075-1088. [CrossRef]

125. Szente, L.; Singhal, A.; Domokos, A.; Song, B. Cyclodextrins: Assessing the impact of cavity size, occupancy, and substitutions on cytotoxicity and cholesterol homeostasis. Molecules 2018, 23, 1228. [CrossRef]

126. Doherty, G.J.; McMahon, H.T. Mechanisms of Endocytosis. Annu. Rev. Biochem. 2009, 78, 857-902. [CrossRef]

127. Swanson, J.A.; Yoshida, S. Macropinocytosis. In Encyclopedia of Cell Biology; Academic Press: Cambridge, MA, USA, 2015; ISBN 9780123944474.

128. Kou, L.; Sun, J.; Zhai, Y.; He, Z. The endocytosis and intracellular fate of nanomedicines: Implication for rational design. Asian J. Pharm. Sci. 2013, 8, 1-10. [CrossRef]

129. Sahay, G.; Alakhova, D.Y.; Kabanov, A.V. Endocytosis of nanomedicines. J. Control. Release 2010, 145, $182-195$. [CrossRef] [PubMed]

130. Fenyvesi, F.; Réti-Nagy, K.; Bacsó, Z.; Gutay-Tóth, Z.; Malanga, M.; Fenyvesi, É.; Szente, L.; Váradi, J.; Ujhelyi, Z.; Fehér, P.; et al. Fluorescently labeled methyl-beta-cyclodextrin enters intestinal epithelial Caco-2 cells by fluid-phase endocytosis. PLoS ONE 2014, 9, e84856. [CrossRef] [PubMed]

131. Plazzo, A.P.; Höfer, C.T.; Jicsinszky, L.; Fenyvesi, É.; Szente, L.; Schiller, J.; Herrmann, A.; Müller, P. Uptake of a fluorescent methyl- $\beta$-cyclodextrin via clathrin-dependent endocytosis. Chem. Phys. Lipids 2012, 165, 505-511. [CrossRef]

132. Wei, H.; Zheng, W.; Diakur, J.; Wiebe, L.I. Confocal laser scanning microscopy (CLSM) based evidence for cell permeation by mono-4-(N-6-deoxy-6-amino- $\beta$-cyclodextrin)-7-nitrobenzofuran (NBD- $\beta$-CyD). Int. J. Pharm. 2011, 403, 15-22. [CrossRef]

133. Onodera, R.; Motoyama, K.; Tanaka, N.; Ohyama, A.; Okamatsu, A.; Higashi, T.; Kariya, R.; Okada, S.; Arima, H. Involvement of Autophagy in Antitumor Activity of Folate-appended Methyl- $\beta$-cyclodextrin. Sci. Rep. 2015, 4, 4417. [CrossRef]

134. Hirama, T.; Fairn, G.D. Induction of spontaneous curvature and endocytosis: Unwanted consequences of cholesterol extraction using methyl- $\beta$-Cyclodextrin. Commun. Integr. Biol. 2018, 11, 1-4. [CrossRef]

135. Zuhorn, I.S.; Kalicharan, R.; Hoekstra, D. Lipoplex-mediated Transfection of Mammalian Cells Occurs through the Cholesterol-dependent Clathrin-mediated Pathway of Endocytosis. J. Biol. Chem. 2002, 277, 18021-18028. [CrossRef] 
136. O’ Neill, M.J.; Guo, J.; Byrne, C.; Darcy, R.; O’Driscoll, C.M. Mechanistic studies on the uptake and intracellular trafficking of novel cyclodextrin transfection complexes by intestinal epithelial cells. Int. J. Pharm. 2011, 413, 174-183. [CrossRef]

137. Chen, F.W.; Li, C.; Ioannou, Y.A. Cyclodextrin Induces Calcium-Dependent Lysosomal Exocytosis. PLoS ONE 2010, 5, e15054. [CrossRef] [PubMed] article distributed under the terms and conditions of the Creative Commons Attribution (CC BY) license (http://creativecommons.org/licenses/by/4.0/). 